\title{
Life cycle assessment of a bioelectrochemical system as a new technological platform for biosuccinic acid production from waste
}

\author{
Amandine Foulet ${ }^{a}$, Théodore Bouchez ${ }^{b}$, Elie Desmond-Le Quéméner ${ }^{c}$, Lucas Giard ${ }^{a}$, Laure \\ Renvoisé $^{d}$ and Lynda Aissani ${ }^{a}{ }^{*}$
}
a. Irstea, UR OPAALE, F-35044 Rennes, France.
b. Irstea, UR HBAN, F-92761 Antony, France.
c. LBE, INRA, Narbonne, France.
d. Suez Environnement - CIRSEE, Le Pecq, France
* Correspondence to: lynda.aissani@irstea.fr

Abstract Waste management is a key environmental and socio-economic issue. Environmental concerns are encouraging the use of alternative resources and lower emissions to air, water and soil. Innovative technologies to deal with waste recovery that produce marketable bio-products are emerging. Bioelectrochemical synthesis systems (BESs) are based on the primary principle of transforming organic waste into added-value products using microorganisms to catalyse chemical reactions. This technology is at the core of a research project called BIORARE (BIoelectrosynthesis for ORganic wAste bioREfinery), an interdisciplinary project that aims to use anaerobic digestion as a supply chain to feed a BES and produce target biomolecules. This technology needs to be driven by environmental strategies. Life Cycle Assessment (LCA) was used to evaluate the BIORARE concept based on expert opinion and prior experiments for the production of biosuccinic acid and waste management. A multidisciplinary approach based on biochemistry and process engineering expertise was used to collect the inventory data. The BES design and the two-step anaerobic digestion process have many potential impacts on air pollution or ecotoxicity-related categories. The comparison of the BIORARE concept with conventional fermentation processes and a water-fed BES technology demonstrated the environmental benefit resulting 
from the use of both the BES technology and a waste-based substrate as input thus supporting the BIORARE concept. Some trade-offs among the impact categories were identified but led to options to improve the concept. BES design and synergy management may improve the environmental performance of the BIORARE concept.

Keywords: life cycle assessment, biorefinery, anaerobic digestion, biogas plant, synergies, succinic acid

\section{Introduction}

In the 28 member states of the European Union, several hundred kilograms of municipal waste are generated per capita every year (European Commission 2018). According to the Waste Framework Directive (WFD) (European Parliament 2008), waste management strategies should follow a hierarchy: prevention, preparing for re-use, recycling, matter recovery, energy recovery and, as the least desirable option, disposal. Disposal as a solution to get rid of waste is subject to debate particularly for municipal bio-waste for which landfilling and incineration do not represent the best overall environmental outcome (Evans 2001; Yadav and Samadder 2018). Amongst municipal bio-waste treatment methods, anaerobic digestion enables stabilization of household organic wastes while producing bio-based added-value outputs, which are the biogas and the digestate. The biogas, which is composed of methane $\left(\mathrm{CH}_{4}\right)$ and carbon dioxide $\left(\mathrm{CO}_{2}\right)$, can be energetically recovered in a combined heat and power (CHP) unit, also known as a cogeneration unit, or injected into the natural gas grid (Zhang et al. 2016). This makes slashing greenhouse gas emissions possible and also reduces energy costs by recycling waste energy. As for the digestate, it can be used to fertilise agricultural soils because of its nitrogen and phosphorus content. Given the above useful outcomes, anaerobic digestion has become the focus of an increasing number of innovative integrated technologies (Yan et al. 2010; Ras et al. 2011; Fouilland et al. 2014; EscamillaAlvarado et al. 2017). Coupling anaerobic digestion with engineered processes has the advantage of treating waste-related streams at the same time as generating added-value products, as it was recently shown by Reddy et al. (2018). 
When used in electrochemical processes, microbial catalysts provide interesting new opportunities for waste conversion. Bioelectrochemical systems (BESs) are recent technologies which enable the conversion of $\mathrm{CO}_{2}$ into organic chemicals by microorganisms, as well as other applications (Rabaey and Rozendal 2010a). BESs basically consist in catalysing oxidation and reduction reactions at an anode or a cathode, respectively, using the metabolic abilities of electroactive microorganisms. When the system is used to harvest energy, the BES is called a microbial fuel cell (MFC). When the energy is invested in the system, the BES is called a microbial electrolysis cell (MEC). BES technology has attracted considerable attention because it can serve several purposes such as waste treatment, $\mathrm{CO}_{2}$ reduction and generation of biofuels, electricity, hydrogen and chemicals (Rozendal et al. 2008b; Wrana et al. 2010; Logan and Rabaey 2012; Sun et al. 2016). Opportunities to sell high added-value products produced from low-cost resources such as waste biomass can be exploited by integrating BESs in established technologies. In addition to the contribution of BESs combined with enhanced treatment and resource recovery technologies for sustainable wastewater treatment (Li et al. 2014), a prospective study was conducted by Sadhukhan et al. (Sadhukhan et al. 2016) on inherently integrated microbial electrolysis systems within biorefineries. This work increases the possibility of exploiting the effectiveness of combining biological and electrochemical processes towards a synergistic polygeneration system.

Here we report on a case study in which a BES was coupled with anaerobic digestion because the latter can provide energy and resources to the former. This approach is the main objective of the "BIoelectrosynthesis for ORganic wAste bioREfinery" (BIORARE) project. Based on scientific, technical, environmental and economic knowledge, the project aims to identify the key components and associated specifications for the elaboration of a future industrial development strategy. According to the BIORARE concept, organic waste will undergo an ambitious recovery process instead of disposal or simple conversion into biogas and digestate. However, the BES concept is not yet a fully developed technology with a Technology Readiness Level (TRL) 4 "Component and/or breadboard validation in laboratory 
environment" (Mankins 1995; European Commission 2014). To identify the environmental benefits and costs of a breakthrough technology undergoing process development, an evaluation was undertaken using a life cycle approach. Supported by ISO standards (ISO 2006a, b), Life cycle assessment (LCA) is a tool which enables the quantification of the potential environmental impacts of a product or a process throughout its life cycle. LCA has been widely used to assess goods, services, processes including processes in their early development in an eco-design approach (Azapagic 1999; Patel et al. 2012; Espinosa et al. 2015; Mitterpach et al. 2017; Farahani and Asoodar 2017). However, a comparative LCA of non-mature systems with other systems, either non-mature or already up-scaled, is not an easy task because of the lack of step back and sufficient available data for a relevant LCA. Indeed, in this case, the necessary quantification of inventory data, mass and energy balance and scale-up is an ongoing challenge.

The objective of performing LCA in this case was not to conduct an in-depth environmental evaluation of a specific scenario but rather to produce a "picture" of the environmental performances of an original but not yet mature system. So far, LCAs of BESs are rare. To our knowledge, Foley et al. (2010) published the first LCA of compared systems based on anaerobic digestion, MFCs, and MECs, in the context of wastewater treatment and on-site production of chemicals. These authors showed that this kind of assessment depends to a great extent on basic assumptions, especially on the materials used to build the reactor and the target performance; a point also made by Francmanis et al. (2016). Research based on futuristic application of BESs in order to produce molecules of interest whilst treating waste is rare but offers many possibilities for the development of environmental biorefineries (Lovley 2006; Rozendal et al. 2008a; Srikanth et al. 2016). Despite the lack of environmental data on product generation through BESs, LCA practitioners willing to study BES based technologies can refer to published guidelines (Pant et al. 2011) and to the work presented in this paper. A market study showed that demand for biosuccinic acid could increase considerably in the near future, along with a large commodity chemical market for various applications such as 
plasticizers, polyurethanes, bioplastics, and chemical intermediates (Weastra 2012). This is why the BIORARE concept was directed towards the production of biosuccinic acid, especially given that French and European markets for biosuccinic acid are still in their infancy.

This paper makes several innovative contributions:

- A potential environmental positioning of the coupled system "anaerobic digestion /BES" when compared to alternative systems of production

- A sustainability driven strategy to optimise the coupling system

And also:

- An integrated waste treatment line (anaerobic digestion) and BES process modelling

- An insight into the environmental performance of the integrated system as a function of the targeted biomolecules

We now present the methodology based on process engineering. Our methodology is coupled with LCA in a context of not yet mature technology. This approach makes it possible to orient an upstream technology towards pollution prevention. Comparative LCAs are used to discuss whether or not BIORARE concept is more environmentally efficient than the industrial production from sugar fermentation and the production from a water-fed BES technology.

\section{Materials and methods}

In this section, we describe the BIORARE concept to provide a detailed framework of the synergy between a BES and anaerobic digestion (AD). The LCA method is also briefly described before being used for the environmental assessment of the BIORARE concept.

\section{The BIORARE concept}

The innovative aspect of coupling $\mathrm{AD}$ with a BES is treating municipal bio-waste in two steps, as shown in Figure 1. The first step is fermentation, which produces a substrate rich in 
volatile fatty acids (VFAs) intended to feed the BES, and an anaerobic digestion plant as a valuable source of energy, in the form of biogas.

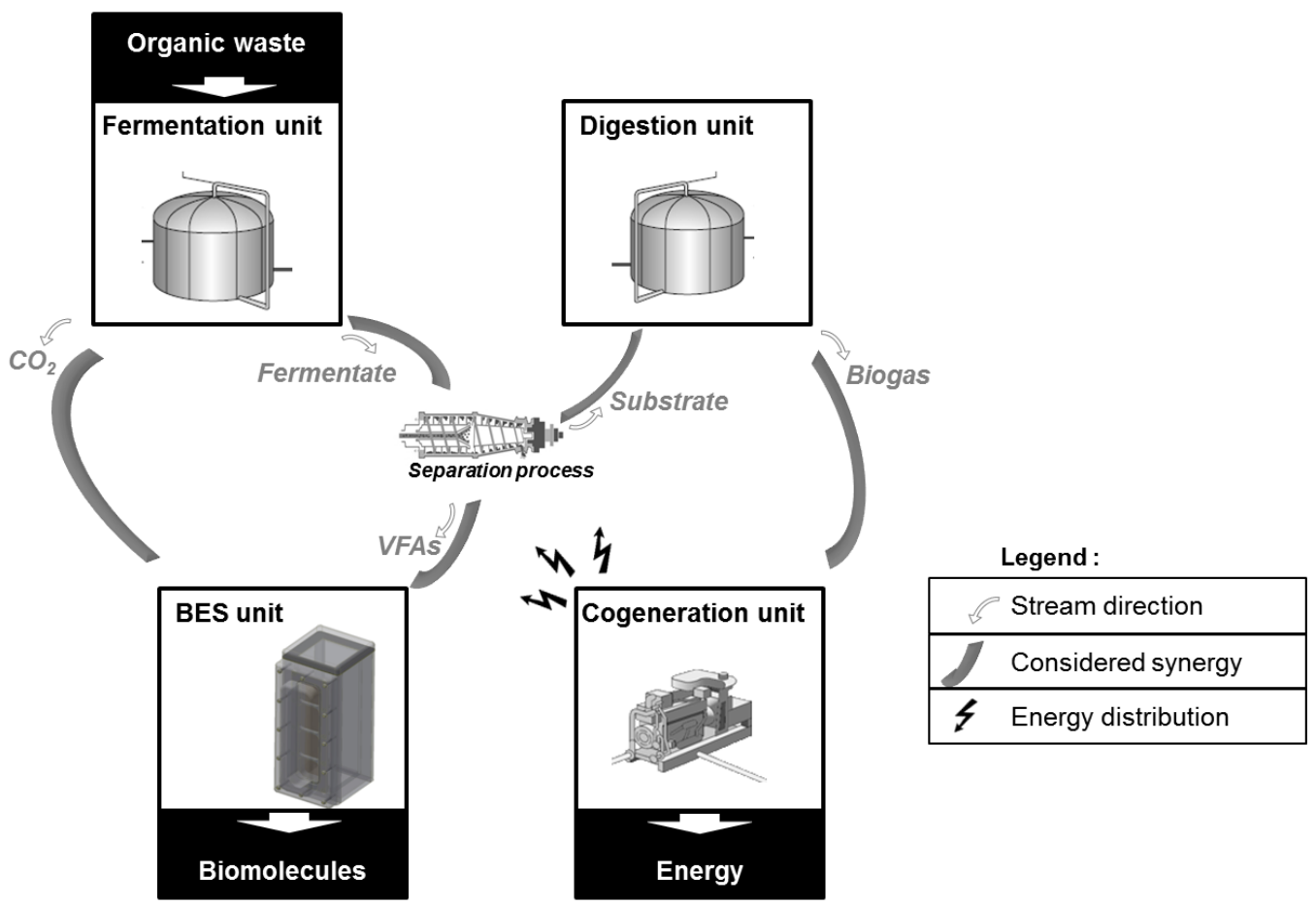

Fig. 1 Schematic representation of the BIORARE concept including the potential synergies between the unit processes

The BES process is the central element of the BIORARE concept. It is composed of two compartments separated by a membrane; both compartments contain a bio-electrode made of carbon fibres and host microorganisms (see Figure 2).

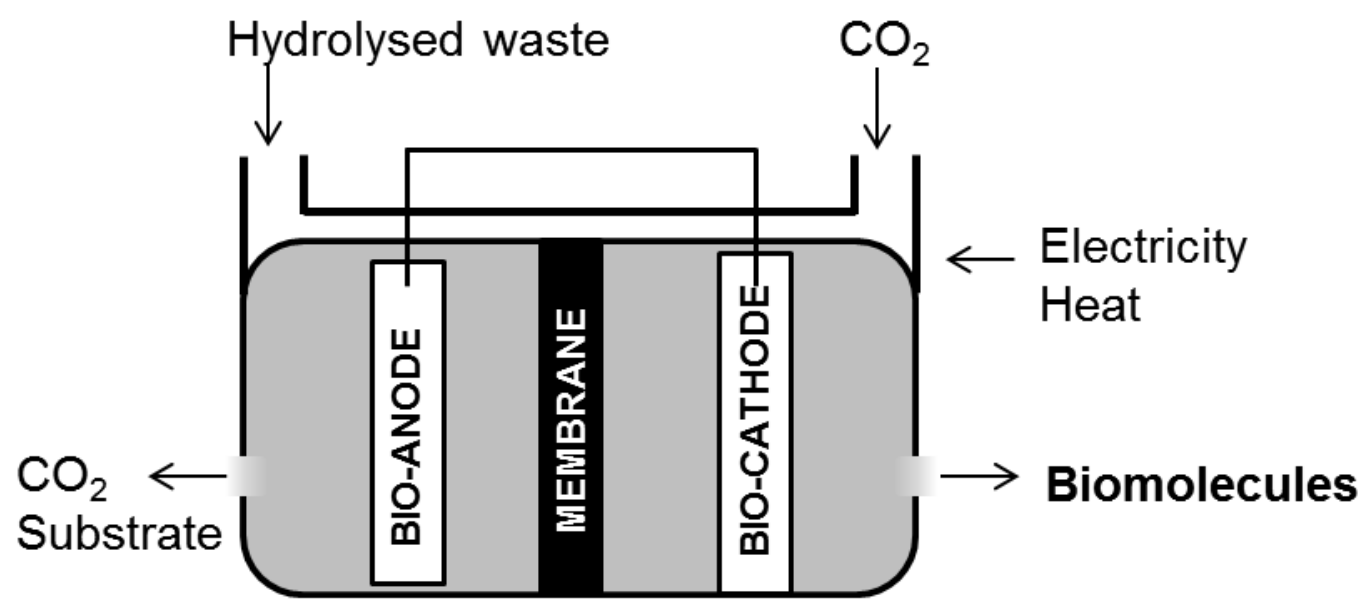

Fig. 2 Diagram of the BES process in the MEC mode. Electroactive microbial communities develop in contact with the electrodes, which are connected by an electrical circuit to ensure electron transfer 
The BES requires different inputs. Electricity and heat have to be supplied to both compartments. A source of carbon $\left(\mathrm{CO}_{2}\right)$ is required in the bio-cathode compartment, and a hydrolysed waste, which is rich in volatile fatty acids (VFAs), is required in the bio-anode compartment.

Microbiological reactions take place in both compartments. In the bio-anode compartment of the BES, a consortium of electrogenic microorganisms (especially Geobacter sulfurreducens) transforms the input (substrate) into electrons (eq. 1-3) which are then transported to the biocathode (Lovley 2006; Moscoviz et al. 2017);

Acetate $+2 \mathrm{H}_{2} \mathrm{O} \rightarrow 2 \mathrm{CO}_{2}+7 \mathrm{H}^{+}+8 \mathrm{e}^{-}$

Propionate $+4 \mathrm{H}_{2} \mathrm{O} \rightarrow 3 \mathrm{CO}_{2}+13 \mathrm{H}^{+}+14 \mathrm{e}^{-}$

Butyrate $+6 \mathrm{H}_{2} \mathrm{O} \rightarrow 4 \mathrm{CO}_{2}+19 \mathrm{H}^{+}+20 \mathrm{e}^{-}$

In the bio-cathode compartment hosting Clostridium pasteurianum, electrons are used to reduce $\mathrm{CO}_{2}$ leading to the production of the targeted bio-based chemical (eq. 4) which is finally purified.

$$
4 \mathrm{CO}_{2}+14 \mathrm{H}^{+}+14 \mathrm{e}^{-} \rightarrow \text { Biosuccinic acid }+4 \mathrm{H}_{2} \mathrm{O}
$$

In this process, it would be an advantage if the BES material came from a recovery/recycling system. By coupling the BES with an anaerobic digestion plant, it would be possible to produce the required substrate, heat and electricity, as shown in Figure 1. Anaerobic digestion with a pre-fermentation step would be the appropriate type of organic waste treatment to make it possible to send a phase rich in carbon compounds (in a gaseous form) to the BES. A pre-fermentation step would enable the production of a liquid substrate rich in VFAs (acetate, propionate and butyrate). In addition, the $\mathrm{CO}_{2}$ resulting from the degradation of organic matter during fermentation would cover $90 \%$ of the $\mathrm{CO}_{2}$ input to the $\mathrm{BES}$ at the bio-cathode (the remaining $10 \%$ would be provided by the $\mathrm{CO}_{2}$ produced at the bio-anode). The flow of gas would be directly injected into the bio-cathode compartment, while, after decantation and separation, VFAs would be injected into the bio-anode compartment. The rest of the substrate would be sent to the digestion unit to produce biogas composed of $60 \mathrm{v} . \%$ of methane $\left(\mathrm{CH}_{4}\right)$ 
and $40 \mathrm{v} . \%$ of $\mathrm{CO}_{2}$. Electricity and heat would be required for most of the process in the system and supplied directly by a cogeneration unit in which the biogas is burned. Although this coupling is theoretically possible, there are no references to it in the literature and there is a general lack of knowledge in this field. This promising bio-based chemical method of production needs to be investigated as it has two advantages: producing bio-based chemicals (in the bio-cathode) by treating municipal bio-waste (in the bio-anode).

\section{Life Cycle Assessment}

\section{LCA framework}

LCA is the «compilation and evaluation of the inputs, outputs and the potential environmental impacts of a product system throughout its life cycle » (ISO 2006a). ISO standards (ISO 2006a, b) and ILCD Handbook (European Commission 2010a, b) provide a frame and guidelines on how to conduct a LCA study. LCA practitioners are requested to refer to these three sources. LCA is an iterative process, consisting in four steps (see Figure 3), summarised below.

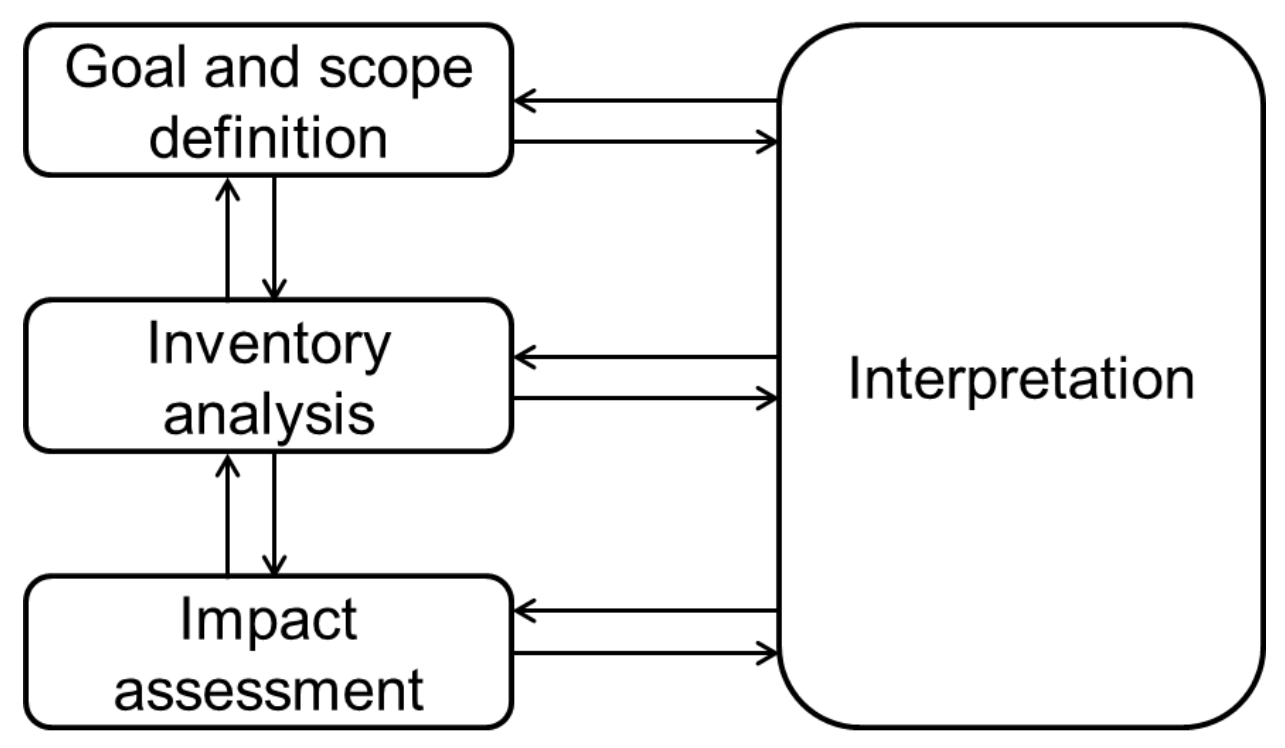

Fig. 3 The four mandatory stages of a LCA, adapted from ref (ISO 2006b)

The very first step is of primary importance. The LCA practitioner describes, amongst other things, the boundaries of the system, its functions, the functional unit and the allocation rules. The inventory analysis step consists in the quantification of the exchanges between the 
studied system and its environment. This step is conducted throughout data collection, data assessment, modelling, etc.. During this step, a matter and energy balance of the system has to be performed. From the inventory, the potential environmental impacts of the system are quantified by characterisation. Depending on the method, it is possible to assess around ten main impact categories, among which depletion of abiotic resources; acidification; eutrophication; marine, freshwater, and terrestrial ecotoxicity; climate change; human toxicity; photochemical ozone formation and depletion of the ozone layer. The final step is the interpretation of the results with regard to the three first steps. This step provides the opportunity to check the consistency and completeness of the study and to perform sensitivity analysis to determine how changes in data and methodological choices would affect the results of the LCA.

\section{Goal and scope definition}

The purpose of the present paper is to describe the potential environmental benefits and drawbacks of BIORARE technology by taking various parameters into account via attributional LCA methodology. The BIORARE strategy consists in producing bio-based molecules. The choice of the chemical was based on the theoretical possibility of producing it with a BES. Another criterion of choice was the advantage for the environmental of local waste-based production. Biosuccinic acid production was chosen for the present study. Biosuccinic acid is produced from the transformation of carbon sources such as glucose and glycerol with yields over 1.1 gram of succinic acid per gram of total sugar (Cao et al. 2013; Fung Lam et al. 2014; Bretz 2015).

ISO 14040 (ISO 2006b) and ISO 14044 (ISO 2006a) standards define 'functional unit' as the "quantified performance of a product system for use as a reference unit". The performance should be in agreement with the objective of the system, as it reflects its function. Coupling a BES technology with an anaerobic digestion plant leads to a multifunctional system, meaning that more than one function is fulfilled. The BIORARE concept will serve two functions that need to be quantified: the production of biosuccinic acid and the treatment of municipal bio- 
waste. To determine a quantity for the functional unit, constraints in the process must be defined. As the main goal of coupling is to produce bio-based molecules, the quantification of the functions is based on the assumed quantity of biosuccinic acid produced using the BES technology. There are two possible ways to define this quantity: calculations based on predictions concerning the market for bio-based chemicals or an arbitrary calculation. At this stage of BES operations, the BIORARE consortium chose an arbitrary quantity of one kiloton of biosuccinic acid per year. Treating organic waste is a fortunate side effect. In cases of LCA for waste management "the functional unit must be defined in terms of system's input" (Pant et al. 2011). In order to reach the defined production goal, the functional unit of the BIORARE scenario is "35 kilotons of municipal bio-waste to produce one kiloton of biosuccinic acid".

\section{System boundary}

The BIORARE scenario studied here includes all the main process units, fermentation of municipal bio-waste preceded by a hygienisation step, anaerobic digestion of the substrate, BES, purification of the biomolecules, cogeneration and spreading of the digestate, as shown in Figure 4. Emissions to air, water and soil compartments are taken into account as are the manufactured products (carbon electrodes, membrane and chemicals) and energy (electricity and heat) required. In most LCA studies based on waste reuse (Foulet et al. 2015; Pradel et al. 2016), no burden is allocated to the waste input and so the latter was also excluded from the boundary of the BIORARE scenario. As in most LCA comparative studies, infrastructures (civil engineering and transports) were also omitted as they are irrelevant in the present case. 


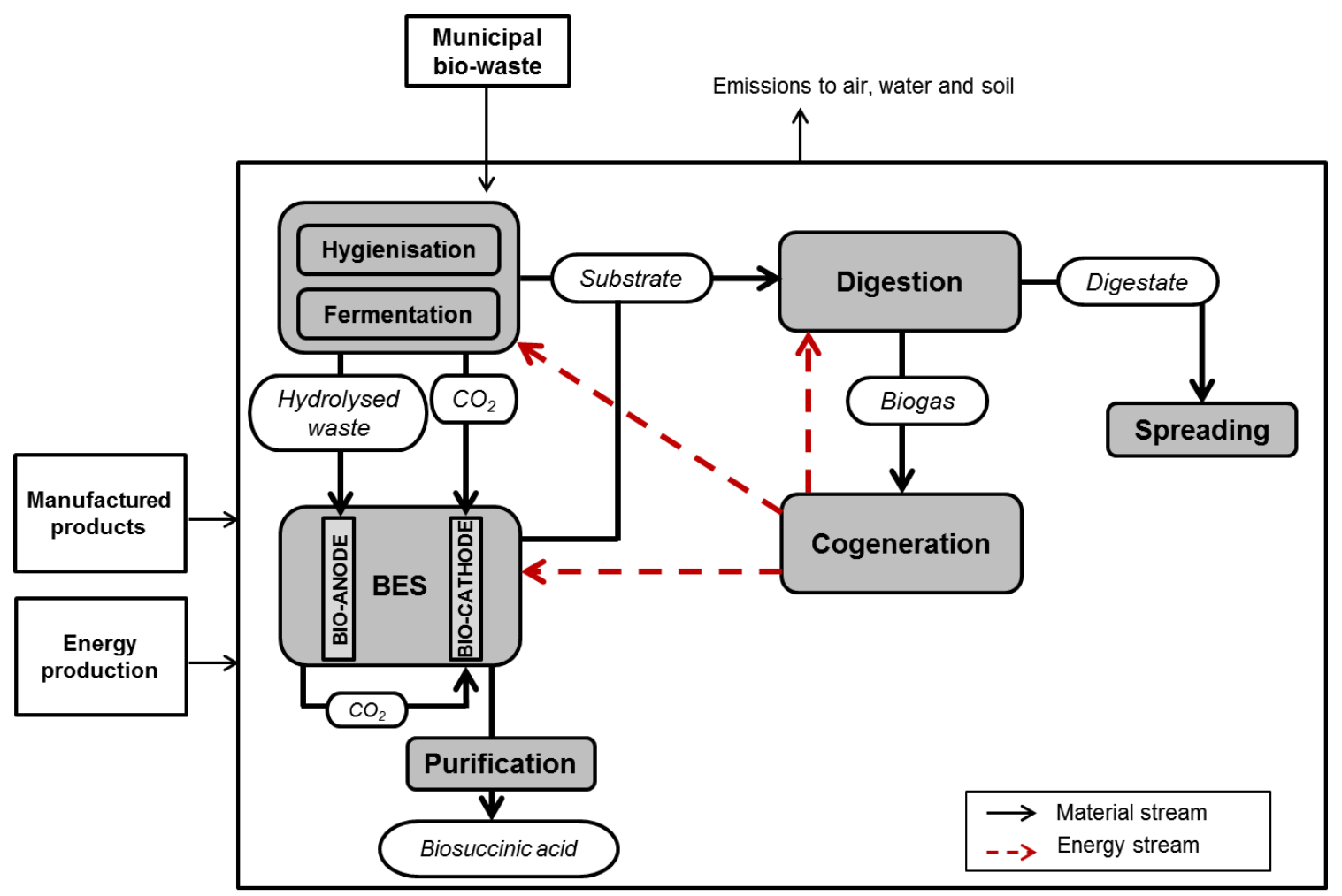

"BIORARE scenario » boundary

Fig. 4 Simplified diagram of the BIORARE coupling scenario showing the boundary of the studied system

\section{Alternative scenarios}

In order to highlight the environmental performances of the BIORARE concept, we need to compare it to alternative cases of biosuccinic acid production. The BIORARE concept is thus first compared to standard production methods, here referred as a "business-as-usual" (BAU). The environmental benefits or burdens of using a BES instead of a classical sugar-based fermentation process will be highlighted by this comparison. The latter may reject the interest of using a waste-based substrate. For that reason, we also compare the BIORARE concept with the same coupling concept except that water is used instead of the waste-based substrate.

BAU for bio-based succinic acid production: Although succinic acid is mainly produced using petrochemical based technologies, fermentation is already used by a number of companies including Reverdia, Myriant, Bioamber and BASF. Reverdia and Myriant production plants are the most widely referred to in the literature (U.S. Department of Energy 2010; Cok et al. 2014; Pinazo et al. 2015; Dunn et al. 2015). The standard way to produce bio-based succinic acid is by microbial fermentation of glucose obtained from different 
sources. Myriant is an American biorefinery and uses sorghum grits as its starting material. However, as sorghum is not a common crop Europe, it was replaced in this study by an abundant low cost, sugar-rich European crop, sugar beet as the production of succinic acid was proved to be achievable from sugar beet (Sutton and Doran-Peterson 2001; Morales et al. 2016; Kootstra 2017). The data available on biosuccinic acid production from sorghum grits (Pinazo et al. 2015) were adapted to the case of sugar beet based on the sugar content of the two starting materials (Zabed et al. 2014). In the fermentation step, molasses from sugar beet was diluted with water, inoculated with Myriant's proprietary microorganism, and incubated to allow the microorganisms to convert glucose into a biosuccinic acid salt. During product recovery, the stream was separated into biosuccinic acid and ammonium sulphate (AMS). Whereas its competing companies lead in bacteria production processes, Reverdia is the only company currently using a low-pH yeast for fermentation. The fermentation process is followed by downstream processes such as direct crystallization, which is the conventional method for the recovery of organic acids from fermentation broth (Cok et al. 2014). In this article, the Myriant and Reverdia biosuccinic acid production systems are also coupled with two-step anaerobic digestion and are hereafter referred to as the "Myriant" and "Reverdia" scenarios.

Water-based BES: A wide range of choices is possible regarding BES design as well as the input to be oxidized in the anode compartment. So far, this paper has dealt only with microbiologically catalysed oxidation of anode inputs. However an electrochemical system can also be chemically catalysed as is the case for water oxidation using a BES for the production of molecules (Rabaey and Rozendal 2010a; Conrado et al. 2013). To compare the BIORARE scenario with a similar method of production of biosuccinic acid, a scenario was built based on the coupling of anaerobic digestion and a water-based BES, hereafter "waterBES”. As shown in Figure 5, water oxidation takes place in the anode compartment on a steel abiotic electrode according to the following equation: $\mathrm{H}_{2} \mathrm{O} \rightarrow 2 \mathrm{H}^{+}+\frac{1}{2} \mathrm{O}_{2}+2 e^{-}$. Contrary to the BIORARE BES unit, here the anode compartment hosts no microorganisms and the 
anode works electrochemically. The bio-cathode compartment of the water-BES is similar to the BIORARE BES, i.e. the reduction of $\mathrm{CO}_{2}$ in microbial conditions resulting in the production of biomolecules. The design of the water-BES process is described in the following section.

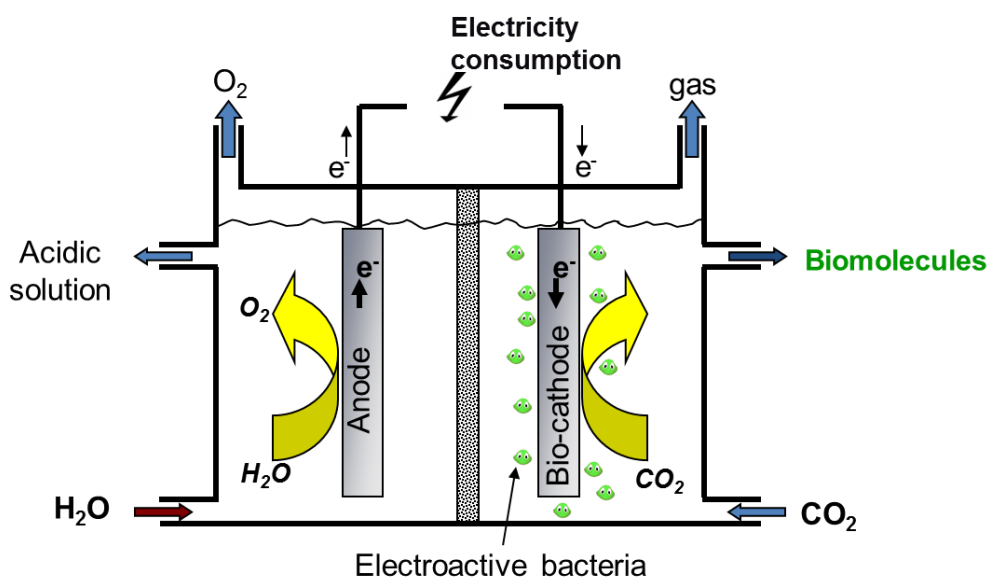

Fig. 5 Schematic representation of the water-based BES system

\section{Inventory and modelling of the coupling of bioelectrosynthesis and anaerobic digestion}

Lab-scale production of biosuccinic acid through the BES is not sufficiently broad based to be comparable with industrial scale technologies. For this reason, the BES designs in the BIORARE scenario and in the water-BES scenario were linearly up-scaled to produce approximately one kiloton of biosuccinic acid. Like for the two-step anaerobic digestion part, the data came from existing plants.

BES design in the BIORARE scenario: The theoretical coupling of BES and anaerobic digestion processes is the main difficulty involved in this study. To build this theoretical coupling in the BIORARE project appropriately, expert opinion, laboratory assays and literature were used to define the BES unit design (Quéméner et al. 2018) (cell volume, the electrode and membrane materials, energy consumption, operational settings, the quantity of carbon required, the chemicals targeted, etc.) together with the scale-up required for its implementation in an anaerobic digestion plant. The design parameters concerned are summarized in Table 1. The collected data either come from the local scientific expertise of 
the authors (mainly Irstea), or from theoretical calculations, or from literature review. The electrochemical parameters, such as current density, the electric potential difference, and the coulombic efficiency were determined in experimental assays in a laboratory belonging to the BIORARE project partners. The working temperature was set at $35{ }^{\circ} \mathrm{C}$ to ensure good working conditions for the microorganisms.

The BES energy requirements (electricity and heat) depend on the quantity of biosuccinic acid produced. The electricity is calculated from the product of the electric potential difference, the current density and the electrode surface, which is estimated following this equation (eq. 5):

$S_{\text {elec }}=\frac{m_{\text {succi }} \times Q_{e^{-} \times n_{e^{-}}}}{J}($ eq. 5$)$

where $S_{\text {elec }}$ is the surface of the electrode in $\mathrm{m}^{2}, m_{\text {succi }}$ is the quantity of biosuccinic acid produced in $\mathrm{kg}, Q_{e^{-}}$is the charge of mole electron in $\mathrm{C}^{\mathrm{mol}}{ }^{-1}, n_{e^{-}}$is the number of electrons exchanged on the electrode surface and $J$ is the current density in A.m ${ }^{-2}$. To estimate the heat input, the quantity of biosuccinic acid produced is multiplied by the heat capacity of water $\left(4,180 \mathrm{~J} \cdot \mathrm{kg}^{-1} \cdot \mathrm{K}^{-1}\right)$ and the temperature difference between the working temperature $\left(35^{\circ} \mathrm{C}\right)$ and the room temperature. The energy requirements are expressed in Table 1 as a function of the dry matter content of the fermentate used as input in the BES. The input of fermentate depends on the chemical oxygen demand (COD) of the BES, in other words, the quantity of volatile fatty acids (VFAs) the bioelectrochemical system can handle. $\mathrm{CO}_{2}$ input depends on the same quantity. 
Table 1 Key data used to estimate input and output streams in the BIORARE system

\begin{tabular}{|c|c|c|c|}
\hline \multicolumn{2}{|c|}{ BIORARE BES operating parameters } & \multicolumn{2}{|c|}{ BIORARE BES design } \\
\hline Current density (A.m²) & 20 (a) & Anode material & carbon cloth $(a)(c)$ \\
\hline $\begin{array}{l}\text { Electric potential difference } \\
\text { (V) }\end{array}$ & 1.14 (a) & Cathode material & carbon cloth $(\mathrm{a})(\mathrm{c})$ \\
\hline $\begin{array}{l}\text { Cathode coulombic efficiency } \\
(\%)\end{array}$ & 85 (a) & $\begin{array}{l}\text { Total active electrode surface for } \\
\text { succinic acid production }\left(\mathrm{m}^{2}\right)\end{array}$ & $2.1 \times 10^{4}(\mathrm{~b})$ \\
\hline Working temperature $\left({ }^{\circ} \mathrm{C}\right)$ & 35 (a) & Electrode thickness (m) & $5.0 \times 10^{-4}(\mathrm{a})$ \\
\hline $\begin{array}{l}\text { Electricity input }\left(\mathrm{J} / \mathrm{kg}_{\mathrm{DM}}\right)^{(1)} \text { for } \\
\text { the production of biomolecules }\end{array}$ & $2.23 \times 10^{6}(\mathrm{~b})$ & Type of membrane & cationic (a)(c) \\
\hline $\begin{array}{l}\text { Heat input }\left(\mathrm{J} / \mathrm{kg}_{\mathrm{DM}}\right) \text { for } \\
\text { biomolecules production }\end{array}$ & $6.28 \times 10^{5}(b)$ & Membrane thickness (m) & $5.0 \times 10^{-5}(\mathrm{a})$ \\
\hline $\begin{array}{l}\mathrm{CO}_{2} \quad \text { cathode input } \\
\left(\mathrm{kg} / \mathrm{kg}_{\text {biosuccinic acid }}\right)\end{array}$ & $0.31(b)$ & & \\
\hline $\mathrm{CO}_{2}$ anode output $\left(\mathrm{g} / \mathrm{g}_{\mathrm{COD}}\right)^{(2)}$ & $1.76(b)$ & & \\
\hline \multicolumn{4}{|l|}{ (1) DM: Dry matter } \\
\hline \multicolumn{4}{|l|}{ (2) COD: Chemical oxygen demand } \\
\hline \multicolumn{4}{|l|}{ (a) optimised experimental conditions } \\
\hline \multicolumn{4}{|c|}{ (b) theoretical calculations from experimental parameters } \\
\hline
\end{tabular}

As mentioned above, the BES cell is composed of two compartments, both containing one electrode, and separated by a membrane. Because of the electrochemical performance of carbon-based bio-electrodes in BESs, and their robustness and economic interest, they appear to be a good choice for the bio-anode and bio-cathode (Wang et al. 2009; Zhang et al. 2013; Bajracharya et al. 2016). Regarding the choice of membrane for this model, we selected a cationic one because it is required to minimize leakage of succinate in the anode compartment. The thickness of the electrode and of the membrane thicknesses were investigated to achieve the best production performances while slowing down the deterioration of the materials. The thickness of the electrode was finally set at $500 \mu \mathrm{m}$ and that of the membrane at $50 \mu \mathrm{m}$. Lab-scale experiments did not enable us to predict the 
lifetime of the BES materials. Previous studies have shown that, depending on the operating conditions, carbon-based electrodes can last more than five years (McCreery 2008; Jourdin 2015; Yang et al. 2016). As there is no real consensus, a lifetime of ten years was chosen in order to maximise the production rate.

A purification step is required to obtain biomolecules whose purity is close to industrial grade $(99.5 \%)$. Like for biosuccinic acid, the purification methods reported in the literature mostly concern biosuccinic acid obtained by fermentation using yeast or bacteria in broth media (Glassner et al. 1995; Huh et al. 2006; Luque et al. 2009; Cao et al. 2013). Typically microfiltration and ultra-filtration are used to remove residual cell debris and proteins. The filtrate is then condensed by vacuum distillation. After distillation, the succinic acid filtrate is titrated with hydrochloric acid $(0.12 \mathrm{~kg} / 1 \mathrm{~kg}$ of filtrate) to crystallise it. Washing and distillation are then necessary to obtain pure biosuccinic acid. Since to our knowledge, no investigation of a method of purification for biosuccinic acid produced by BES has yet been conducted, data and the energy balance were taken from the literature (Luque et al. 2009) and adapted for the present study.

Water-BES design: The water-BES is based on the same technology as the BIORARE BES, with one exception, the anode compartment hosts a water oxidation reaction on an abiotic anode. The choice of the anode material was influenced by the existing literature on water oxidation using electrosynthesis and on the availability of data on its production phase. Stainless steel is a cheap electrode material with low overpotential and its composition (alloy of iron, nickel, chromium and other metals) has been shown to be efficient as a water oxidation catalyst (LeRoy 1983; Schäfer et al. 2015b, a; Yu et al. 2016), as well as to ensure microbial electrocatalysis as a bio-cathode (Dumas et al. 2008; Pocaznoi et al. 2012; Bajracharya et al. 2016). For these reasons, the anode and the bio-cathode of the water-BES were made of stainless steel, while the membrane was cationic, like the membrane in the BIORARE BES (see Table 2). 
In the anodic compartment, the water is oxidised as follows (eq. 6):

$2 \mathrm{H}_{2} \mathrm{O} \rightarrow 4 \mathrm{H}^{+}+\mathrm{O}_{2}+4 e^{-}$(eq.6)

The quantity of water $\left(m_{\mathrm{H}_{2} \mathrm{O}}\right)$ required to produce one kiloton of succinic acid was estimated by the following equation (eq. 7):

$m_{\mathrm{H}_{2} \mathrm{O}}=\frac{J \times M_{\mathrm{H}_{2} \mathrm{O}}}{x_{e^{-} \times C E_{\text {anode }} \times Q_{e^{-}}}} \times t \times S_{\text {anode }}$ (eq. 7); for which all the parameters are listed in the grey cells in Table 2. To reach the biomolecule production target, 0.91 kilotons of water is necessary for succinic acid production. The production of $\mathrm{O}_{2}$ as output of the anodic compartment depends on the input of $\mathrm{H}_{2} \mathrm{O}$ (see eq. 6). Regarding the water-BES energy input, it is estimated following the methodology described in the BIORARE design section.

Table 2 Key data used to estimate the water input in the water-BES scenario

\begin{tabular}{|c|c|c|c|}
\hline \multicolumn{2}{|l|}{ Water-BES parameters } & \multicolumn{2}{|l|}{ Water-BES design } \\
\hline Current density $(J)\left({\left.\mathrm{A} . \mathrm{m}^{-2}\right)}^{-}\right.$ & $20(a)$ & Anode material & stainless steel (a)(c) \\
\hline $\begin{array}{l}\text { Molecular weight of water } \\
\left(M_{\mathrm{H}_{2} \mathrm{O}}\right)\left(\mathrm{g} \cdot \mathrm{mol}^{-1}\right)\end{array}$ & 18 & Cathode material & stainless steel $(a)(c)$ \\
\hline $\begin{array}{l}\text { Charge of one mole electron } \\
\left(Q_{e^{-}}\right)\left(\mathrm{C} \mathrm{mol}^{-1}\right)\end{array}$ & 96,485 & $\begin{array}{l}\text { Total active electrode } \\
\text { surface for succinic acid } \\
\text { production }\left(\mathrm{m}^{2}\right)\end{array}$ & $1.5 \times 10^{4}(\mathrm{~b})$ \\
\hline $\begin{array}{l}\text { Duration of production }(t) \\
\left(\mathrm{s} . \mathrm{year}^{-1}\right)\end{array}$ & $3.15 \times 10^{7}$ & Electrode thickness (m) & $5.0 \times 10^{-4}(b)$ \\
\hline $\begin{array}{l}\text { Electric potential difference } \\
(\mathrm{V})\end{array}$ & 2.24 (a) & Type of membrane & cationic $(\mathrm{a})(\mathrm{c})$ \\
\hline $\begin{array}{l}\text { Anode coulombic efficiency } \\
\left(C E_{\text {anode }}\right)(\%)\end{array}$ & $100(b)$ & Membrane thickness (m) & $5.0 \times 10^{-5}(\mathrm{~b})$ \\
\hline $\begin{array}{l}\text { Cathode coulombic efficiency } \\
(\%)\end{array}$ & 85 (b) & $\begin{array}{l}\text { Electrode and membrane } \\
\text { lifetime (years) }\end{array}$ & $10(\mathrm{c})$ \\
\hline Working temperature $\left({ }^{\circ} \mathrm{C}\right)$ & 35 (a) & & \\
\hline $\begin{array}{l}\text { Electricity input }\left(\mathrm{J} / \mathrm{kg}_{\mathrm{H}_{2} \mathrm{O} \text { input }}\right) \\
\text { for biomolecule production }\end{array}$ & $24.0 \times 10^{6}(\mathrm{~b})$ & & \\
\hline $\begin{array}{l}\text { Heat input }\left(\mathrm{J} / \mathrm{kg}_{\mathrm{H}_{2} \mathrm{O}} \text { input }\right) \text { for } \\
\text { biosuccinic acid production }\end{array}$ & $62.8 \times 10^{6}(b)$ & & \\
\hline $\begin{array}{lr}\mathrm{CO}_{2} & \text { cathode } \\
\left(\mathrm{kg} / \mathrm{kg}_{\text {biosuccinic acid }}\right) & \text { input } \\
\end{array}$ & 1.49 (b) & & \\
\hline $\mathrm{O}_{2}$ anode output $\left(\mathrm{kg} / \mathrm{kg}_{\mathrm{H}_{2} \mathrm{O}}\right)$ & 0.89 (b) & & \\
\hline \multicolumn{4}{|l|}{ (a) optimised experimental conditions } \\
\hline (b) theoretical calculations from experime & parameters & & \\
\hline
\end{tabular}


In order to comply with the functional units, the water-BES is implemented in a two-step AD plant. Since no VFA has to be extracted from the fermentate, the latter is sent directly to the digestion process. Like in BIORARE, the energy recovered from the biogas is distributed among the BES, the fermentation, digestion and purification units, and the $\mathrm{CO}_{2}$ produced by fermentation of the bio-waste is sent to the bio-cathode compartment of the BES.

The same biomolecule purification step is applied as in the BIORARE concept.

Inventory of two-step anaerobic digestion: Particular attention was paid to the inventory of the two-step AD plant respecting existing guidelines on bio-waste management (Manfredi et al. 2011). BIORARE project partners (especially Suez Environnement) provided crucial data based on expert opinion and field experience (Richard 2013) (Table 3). 
Table 3 Characteristics and key data for the inventory of the two-step anaerobic digestion

\begin{tabular}{|c|c|}
\hline \multicolumn{2}{|l|}{ Fermentation (hydrolysis of biowaste) } \\
\hline Dry matter content of waste input (wt\%) & 25 \\
\hline Dry matter content of fermentate input (wt\%) & 20 \\
\hline VM:DM ratio ${ }^{(1)}(\%)$ & 85 \\
\hline $\mathrm{CO}_{2}$ production rate $\left(\mathrm{l}_{\mathrm{CO}_{2}} / \mathrm{kg}_{\mathrm{VM}}\right)$ & 25 \\
\hline Water input $\left(\mathrm{kg} / \mathrm{kg}_{\mathrm{DM}}\right)$ & 6.7 \\
\hline Operating temperature $\left({ }^{\circ} \mathrm{C}\right)$ & 55 \\
\hline Fermentation gas $\mathrm{H}_{2}(\mathrm{v} \%)$ & 20 \\
\hline Fermentation gas $\mathrm{CO}_{2}(\mathrm{v} \%)$ & 80 \\
\hline Gas leak (wt\%) & 5 \\
\hline VFA concentration of fermentate expressed in $\mathrm{g}_{\mathrm{COD}} \cdot \mathrm{l}^{-1}$ & 22.6 \\
\hline \multicolumn{2}{|l|}{ Anaerobic digestion (methanogenis) } \\
\hline $\mathrm{CO}_{2}$ in biogas $(\mathrm{v} \%)$ & 40 \\
\hline $\mathrm{CH}_{4}$ in biogas $(\mathrm{v} \%)$ & 60 \\
\hline $\operatorname{BMP}^{(2)}\left(1 . \mathrm{kg}_{\mathrm{VM}}{ }^{-1}\right)$ & 450 \\
\hline Volatile matter of the substrate (wt.\%) & 15 \\
\hline Gas leak (wt\%) & 5 \\
\hline Biogas produced $\left(\mathrm{kg} / \mathrm{kg}_{\text {susbtrate }}\right)$ & 0.12 \\
\hline Digestate produced $\left(\mathrm{kg} / \mathrm{kg}_{\text {susbtrate }}\right)$ & 0.88 \\
\hline \multicolumn{2}{|l|}{ Cogeneration } \\
\hline Gas flaring (wt\%) & 5 \\
\hline Energy conversion $\left(\mathrm{kWh} / \mathrm{kg}_{\mathrm{CH}_{4}}\right)$ & 9.94 \\
\hline Electricity conversion rate $(\%)$ & 2.8 \\
\hline Heat conversion rate & 38 \\
\hline Gas leak (wt\%) & 5 \\
\hline
\end{tabular}

The quantity of fermentate required to satisfy the demand for VFAs by the BES is based on the dry matter content of the fermentate and the VFA concentration of the dry matter. Based on the characteristics of the municipal bio-waste, namely volatile matter content and its rate of conversion into $\mathrm{CO}_{2}$, the production of $\mathrm{CO}_{2}$ during fermentation was estimated to be $8 \mathrm{~kg}$ for 
$1 \mathrm{~kg}$ of bio-waste. Enough $\mathrm{CO}_{2}$ is produced during fermentation to supply the BES in the BIORARE scenarios. On the other hand, an external source of $\mathrm{CO}_{2}$ is necessary to meet the BES need for the production of biosuccinic acid via the water-BES.

During the anaerobic digestion process, organic matter is broken down by microorganisms resulting in biogas and digestate. The biogas is considered here to be composed of $40 \mathrm{v} . \%$ of $\mathrm{CO}_{2}$ and $60 \mathrm{v} . \%$ of $\mathrm{CH}_{4}$. The production of $\mathrm{CH}_{4}$ matters here because it enables the generation of energy through cogeneration. The methane yield of the substrate is determined by the biochemical methane potential (BMP), which is one of the most widely used analytical methods to estimate the biodegradability of organic substrates under anaerobic conditions. In the present study, 450 litres of $\mathrm{CH}_{4}$ is produced per kilogram of volatile matter in the substrate, which is within the range of municipal bio-waste BMP (Hansen et al. 2004). The energy recovered is then estimated from $\mathrm{CH}_{4}$ production and by taking into account the overall energy conversion factors, and reached up to $12 \mathrm{MJ}$ per kilogram of $\mathrm{CH}_{4}$.

The life cycle models presented in this article were designed using the GaBi 7.2.1 LCA software package (Thinkstep 2016). The foreground life cycle inventory (LCI) data were collected from experimental tests, detailed documents and previous works from the authors' respective institutions. The background life cycle inventory data came from the ecoinvent 2.2 database (molasses from sugar beets, cationic membrane and hydrochloric acid) and PE international (former name of Thinkstep) database (stainless steel electrode, liquid carbon dioxide, process water, process steam from natural gas and French electricity grid mix).

\section{Impact assessment methodology}

A method of characterisation is required to calculate the potential environmental impacts of each scenario. It is the link between the released or consumed substance and its potential environmental impacts. The January 2016 update of the CML-IA method is used in this study (Heijungs et al. 2001). Ten impact categories are included and group all the streams according to their environmental compartments. The categories are abiotic depletion, acidification, 
eutrophication, climate change, ozone depletion, photochemical ozone creation, human toxicity and freshwater, marine and terrestrial ecotoxicity. Since all the scenarios require the use of water, the AWaRe method is used to estimate the water footprint (Boulay et al. 2011, 2015).

\section{Results}

The main aim of this study is to assess the environmental burdens of the BIORARE concept. The BIORARE scenario first needed to be studied alone to identify key contributing elements. Following this analysis, the BIORARE scenario was compared to alternative biosuccinic acid production scenarios. No uncertainty analysis was performed in this study because of the lack of data. Consequently, confidence intervals are not known, but a significance threshold of $20 \%$ was applied. When the difference in the contribution between two scenarios is less than $20 \%$, the results are considered non-significant.

\section{Life cycle assessment of the BIORARE scenario}

The BIORARE scenario comprises several elements. The biomolecule production step is mainly driven by the BES unit whereas the waste treatment part comprises a two-step AD, a spreading process and a cogeneration unit. Each contributes to several impact categories to varying extents depending on the related emissions or background processes such as the production of raw materials. Figure 6 shows the relative contribution of the BES unit including the biomolecule purification step and of the two-step AD (hygienisation, fermentation, digestion and spreading) including the cogeneration unit. 


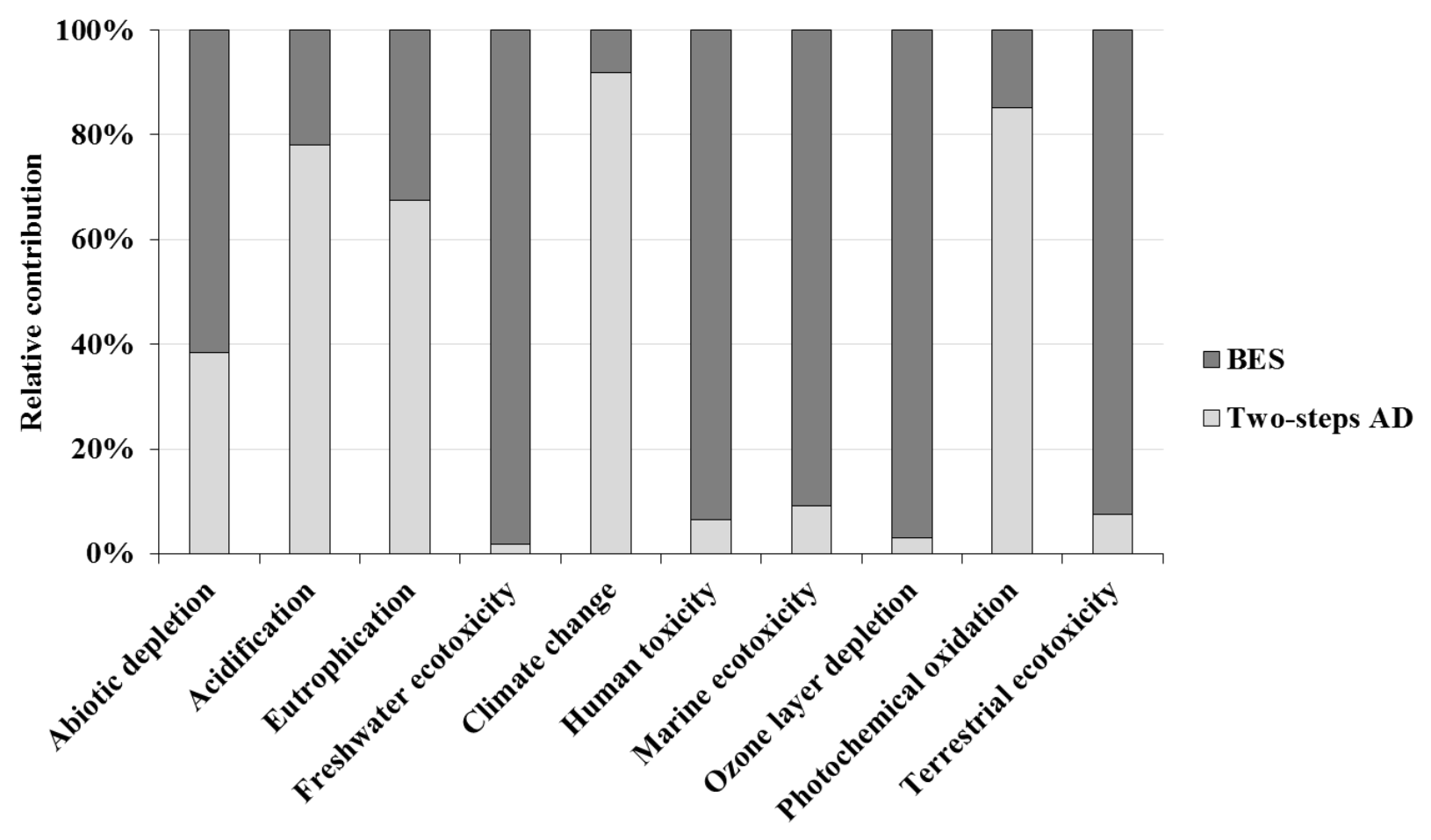

Fig. 6 Life cycle impact assessment (LCIA) results of the production of one kiloton of biosuccinic acid from 35 kilotons of municipal bio-waste in the BIORARE scenario assessed by the CML-IA method (January 2016 update). The ordinate axis represents the contributory part of the BES system and the two-step AD in each impact categories, which are represented on the abscissa axis

Overall, the contribution of the two-step AD and the BES technology were significant. Depending on the impact categories considered, one clearly outweighed the other. The twostep $\mathrm{AD}$ is the item which contributes the most especially in the following impact categories: acidification, eutrophication, climate change and photochemical oxidation. Acidification, eutrophication, climate change and ozone are potential impacts caused by the emissions occurring during the digestion, spreading and cogeneration steps. The spreading process is responsible for the emissions of nitrogenous substances, known to generate free radicals which degrade ozone molecules, and to play a role in acidification and eutrophication phenomena (Heijungs et al. 1992; Tang et al. 1998). Due to emissions of $\mathrm{CH}_{4}$, the digestion process contributes to photochemical pollution as well as to climate change. However climate change is mainly caused by the cogeneration process which converts biogas into energy through a combustion reaction. This process contributes significantly to climate change because of the production of $\mathrm{CO}_{2}$ during biogas combustion, in addition to the initial $\mathrm{CO}_{2}$ in the biogas. Aside from the cogeneration unit, $\mathrm{CO}_{2}$ emissions occur in three other process 
units, fermentation, digestion and BES. As the contribution of biogenic $\mathrm{CO}_{2}$ to climate change is still the subject of debate in scientific and LCA communities (Cherubini et al. 2011, 2013; Guest et al. 2013), the ILCD Handbook recommends presenting both neutral and non-neutral biogenic $\mathrm{CO}_{2}$ contributions to climate change impacts to make the results more transparent (European Commission et al. 2010). To allow LCA practitioners to estimate the potential contribution of biogenic $\mathrm{CO}_{2}$ emissions to climate change, biogenic $\mathrm{CO}_{2}$ is taken into account considering that the main source material of the BIORARE concept is municipal bio-waste. However, no distinct contribution of biogenic $\mathrm{CO}_{2}$ emissions was observable in the LCA results.

Despite its noticeable impacts, the waste treatment part of the BIORARE concept is not the main focus of this study since the true function of the BIORARE concept is the production of biomolecules, which in this case is ensured by the BES unit. The BES unit contributes more to abiotic depletion, human toxicity and all the ecotoxicity-related categories. In order to identify which parameters within the BES unit, the latter is divided into five parts: the direct emissions, the purification step, the electrodes and the membrane materials production, and the electricity consumption (including the background production). As shown in Figure 7, the background production of the electrodes and the membrane do not have a significant impact on every impact category, in contrast to the cost of electricity from grid system. The cost of electricity is nevertheless lowered by the use of renewable energy supply coming from biogas cogeneration. This coupling of energy sources also prevent from electric supply interruption which leads to a decrease in production (del Pilar Anzola Rojas et al. 2018).The purification step also shows a high contribution. The purification of succinic acid contributes significantly to many impact categories, in particular to abiotic depletion, freshwater ecotoxicity, human toxicity, marine ecotoxicity and ozone layer depletion, due to the use of hydrochloric acid. 


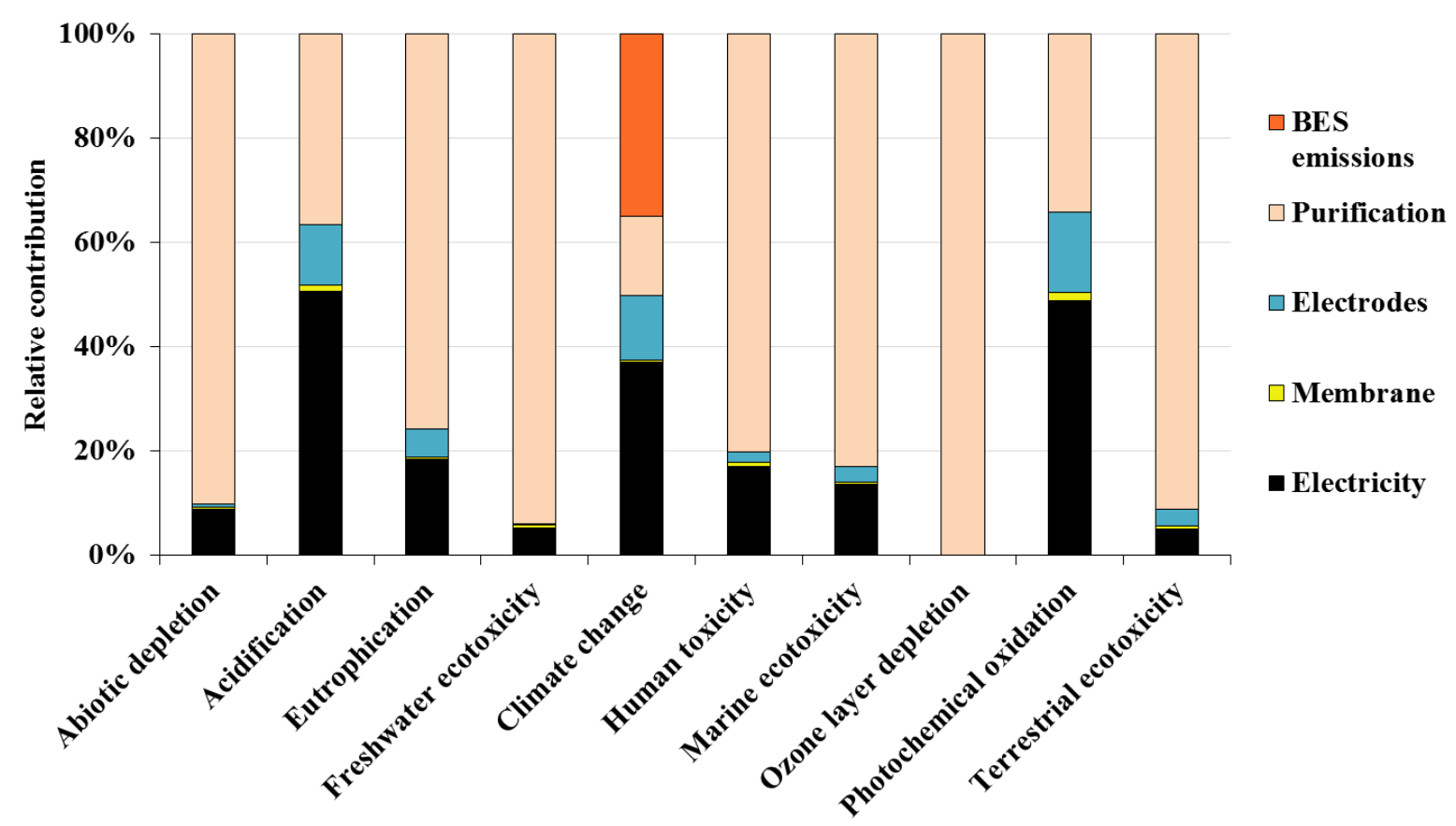

Fig. 7 LCIA of the contribution of one kiloton of biosuccinic acid produced with the BIORARE BES unit from the treatment of 35 kilotons of municipal bio-waste, assessed by the CML-IA method (January 2016 update)

Including a BES unit in waste treatment is shown to have consequences for the environmental profile of the BIORARE scenario. To investigate whether or not the BES contribution to environmental impacts makes the BIORARE scenario less competitive than other methods of production of acid succinic, comparative LCAs are presented in the following sections.

\section{Environmental benefits and burdens of the BIORARE scenario compared to BAU}

In this section, biosuccinic acid production using the BIORARE concept is compared with standard methods of microbial fermentation, i.e. the Reverdia and Myriant processes. Figure 8 shows the comparative LCA of the corresponding scenarios, labelled "BIORARE", "Reverdia" and "Myriant". The BIORARE scenario is competitive for half the impact categories considered, especially acidification, eutrophication, climate change, human toxicity and photochemical oxidation. For the other impact categories, the BIORARE scenario is either less advantageous than the BAU scenarios (abiotic depletion and marine ecotoxicity categories) or less than both BAU scenarios (freshwater ecotoxicity, ozone layer depletion and terrestrial ecotoxicity categories). Since in all the scenarios, the two-step AD aims to treat approximately the same amount of waste, the trade-offs within the impact categories are due 
to the contribution of the biosuccinic acid production technology. The biggest difference in impact is on ozone layer depletion and terrestrial ecotoxicity. As mentioned earlier, this is the consequence of biosuccinic acid purification, which requires a certain amount of hydrochloric acid whose production and use carry heavy environmental burdens. To this extent, it should be emphasized that in the Reverdia and Myriant production processes, purification steps could not be deconvoluated from the production steps. It is therefore not clear if the lower performances of the BIORARE scenario in these impact categories are not due to the BES technology itself compared to fermentation technologies or rather to a difference in the purification technologies considered in each case.

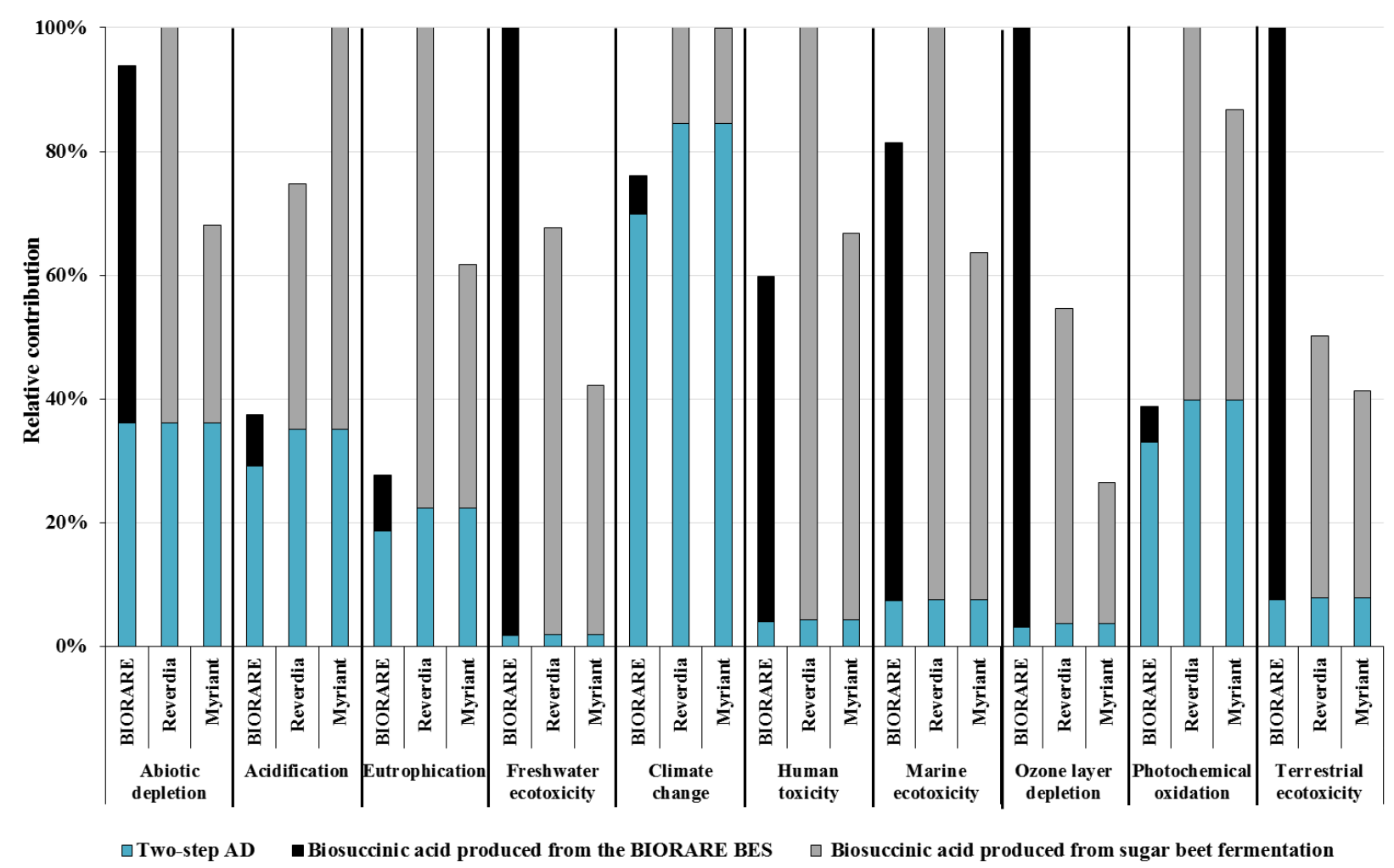

Fig. 8 Results of LCIA comparison of the production of biosuccinic acid in the BIORARE scenario with that in the Reverdia and Myriant scenarios, referred to as BAU scenarios (CML-IA method, January 2016 update)

The BIORARE scenario has to be compared with a scenario based on similar BES technology to objectively evaluate the interest of using a waste-based substrate to produce biosuccinic acid. The following section compares the BIORARE scenario with a system based on a BES which produces biosuccinic acid by water oxidation. 


\section{LCA comparison of the BIORARE scenario with the water-BES technology}

\section{LCA analysis of the water-BES scenario}

In contrast to the BIORARE scenario, the water-based BES scenario (referred to here as water-BES), relies on water oxidation in the anodic compartment to generate electrons which are then used in the bio-cathode compartment for the production of biomolecules. A detailed analysis is shown in Figure 9 to identify the key parameters involved in the environmental burdens of the water-BES. The BES unit is decomposed into seven contributory items: the direct emissions, the purification step, the anode input (water), the bio-cathode input (external source of carbon dioxide), the electrodes and the membrane materials production, and the electricity consumption (including the background production).

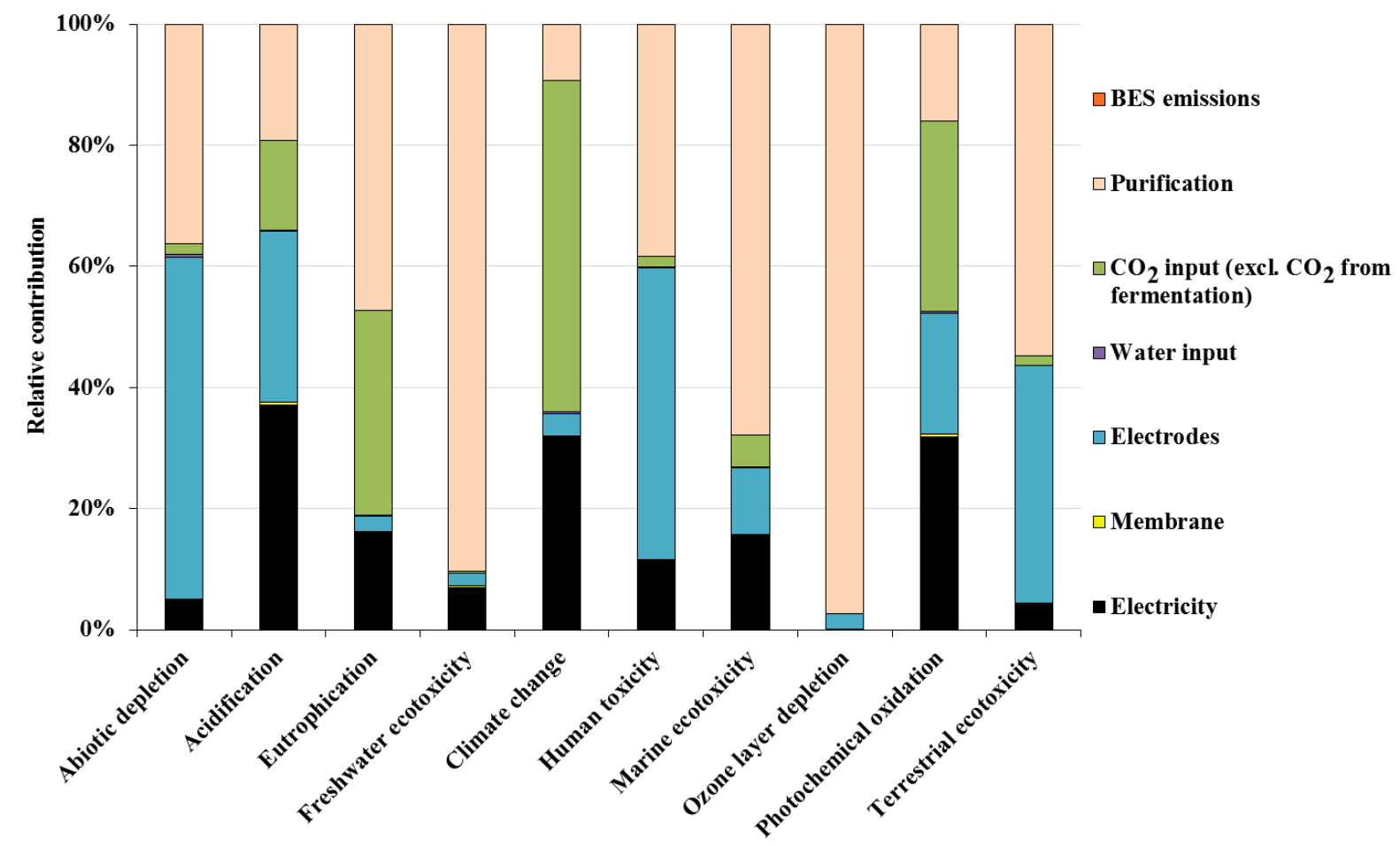

Fig. 9 LCIA of the contribution of biosuccinic acid production using water-based BES to the different impact categories (CML-IA method, January 2016 update)

Seven main parameters were identified as potential environmental burdens in the water-BES scenario, the electricity cost, the membrane, electrodes, water input into the $\mathrm{BES}, \mathrm{CO}_{2}$ input into the BES, the purification step and BES emissions into the air. The potential burdens caused by the $\mathrm{CO}_{2}$ input, the electricity cost and the membrane are less significant but remain 
decisive environmental factors (Figure 9). The purification step stands out from the rest in the same way as in the BIORARE scenario (Figure 7).

\section{Comparison of the BIORARE scenario with the water-BES scenario}

LCA makes it possible to identify the life cycle stages which contribute most to the environmental performances of a system. In Figure 9, the burden of electricity is less pronounced. The BES requires the highest electricity supply of all the units in the BIORARE scenario. The results of quantitative analysis of the electricity production, demand and consumption for the production of one kiloton of acid succinic by the BES unit are shown in Table 4. When expressed as a function of one kilogram of input (dry matter or water), the electricity demand of the water-BES is ten times higher than the electricity demand of the BIORARE BES (see Table 1). However, this demand is less contrasted when the production goal is one kiloton of biomolecules: the electricity demand of the water-BES is only 1.4 higher than the electricity demand of the BIORARE BES.

Other process units, such as hygienisation, fermentation, digestion and purification, also require electricity to operate. To ensure that all the units operate correctly, additional electricity has to be provided to the system. The BES unit, for which the electricity demand represents respectively, $68 \%$ and $74 \%$ of the total electricity demand in the BIORARE scenario and the water-BES scenario, consumes all the electricity produced through cogeneration of biogas. In the BIORARE scenario, $19 \times 10^{6} \mathrm{MJ}$ of additional electricity have to be provided to the system and was attributed to the BES unit since it is the most energy consuming. The same attribution was used in all the scenarios presented in the present study.

In contrast to the electricity burden, the heat burden of the whole system is significantly lower than the heat produced by biogas valorisation. Indeed, dozens of megajoules of heat can be sold to heat networks, as shown in Table 4. 
Table 4 Comparative analysis of the electricity parameters in the BIORARE scenario and the waterBES scenario

\begin{tabular}{|l|c|c|}
\hline \multirow{2}{*}{ Parameter } & $\begin{array}{c}\text { Biosuccinic acid production } \\
(\mathbf{1 , 0 0 0} \text { tons })\end{array}$ \\
\cline { 2 - 3 } & BIORARE & Water-BES \\
\hline Electricity production from biogas $(\mathrm{J})$ & $14.1 \times 10^{12}$ & $17.2 \times 10^{12}$ \\
\hline Electricity input in the BES $(\mathrm{J})$ & $15.4 \times 10^{12}$ & $21.8 \times 10^{12}$ \\
\hline Electricity demand of the whole scenario $(\mathrm{J})$ & $22.7 \times 10^{12}$ & $29.2 \times 10^{12}$ \\
\hline Additional electricity to supply $(\mathrm{J})$ & $8.64 \times 10^{21}$ & $12.0 \times 10^{12}$ \\
\hline Heat production from biogas $(\mathrm{J})$ & $23.5 \times 10^{12}$ & $28.7 \times 10^{12}$ \\
\hline Heat input in the BES $(\mathrm{J})$ & $0.431 \times 10^{12}$ & $0.057 \times 10^{12}$ \\
\hline Heat requirements of the whole scenario $(\mathrm{J})$ & $6.1 \times 10^{12}$ & $5.8 \times 10^{12}$ \\
\hline Heat remaining for sale $(\mathrm{J})$ & $17.4 \times 10^{12}$ & $22.8 \times 10^{12}$ \\
\hline
\end{tabular}

The difference in the contribution in the two scenarios is less than $20 \%$ in three impact categories, meaning that overall, no one scenario is more competitive than the others (Figure 11). This trade-off in impacts is due to the purification step. Between the BIORARE scenario and the water-BES scenario, the hydrochloric acid input and the electricity input of the purification unit are of the same order of magnitude. Therefore both scenarios contribute to the freshwater ecotoxicity, marine ecotoxicity and ozone layer depletion categories. 


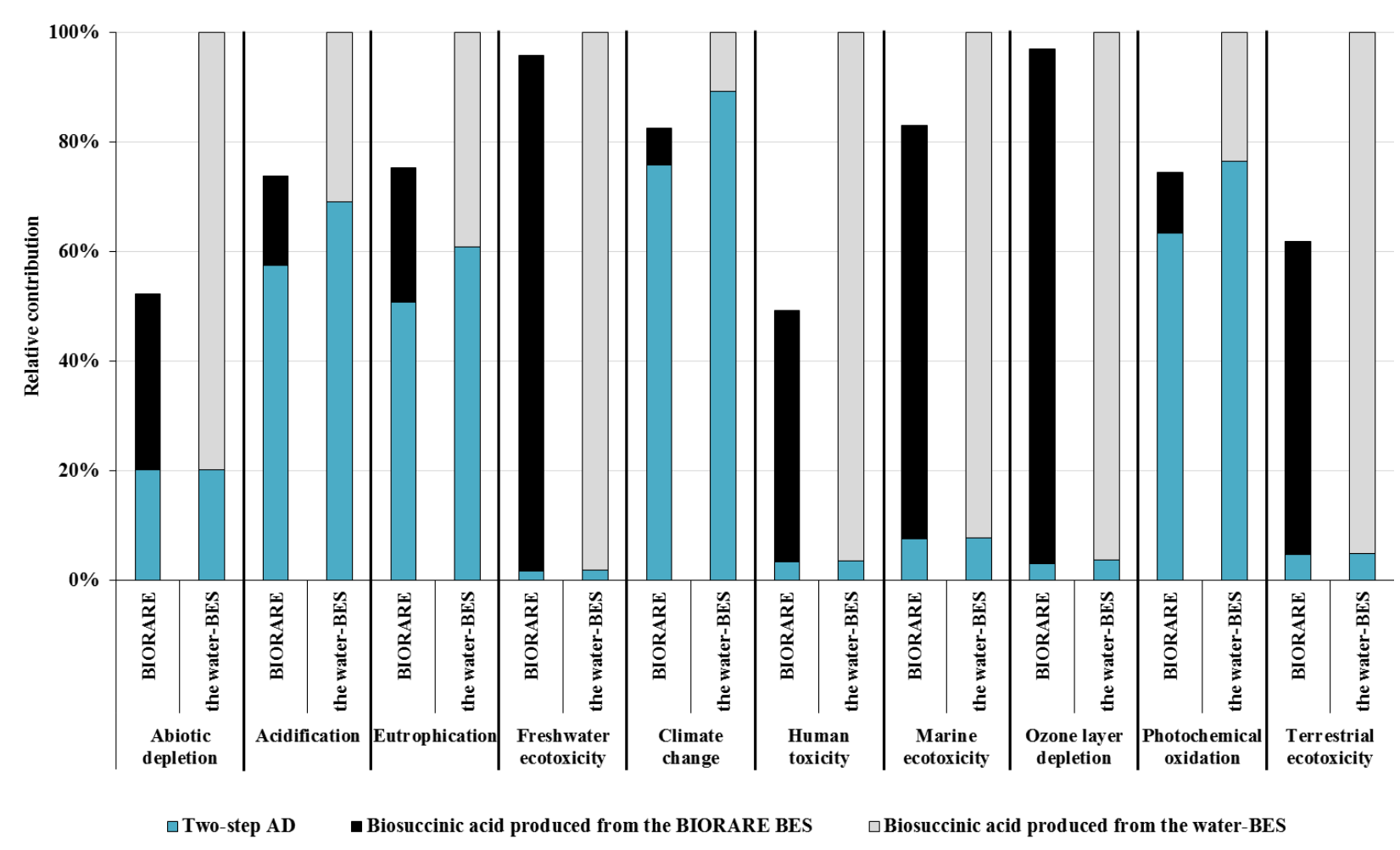

Fig. 10 Comparative LCIA of the BIORARE scenario with the water-based BES scenario for the production of biosuccinic acid, assessed by the CML-IA method (January 2016 update)

\section{Water footprint analysis}

The water input impact is not considered by the CML-IA method. Since the two-step AD system requires water as an input (for fermentation), as well as for the beet farming stage and the water-BES, it is important to model the water footprint in the BIORARE, BAU and waterBES scenarios correctly. For the fermentation process, $6.72 \mathrm{~kg}$ of water are recommended to treat $1 \mathrm{~kg}$ of dry matter (see Table 3) (Richard, 2013). The water input of the water-BES was estimated as previously described. For the beets production, the process was directly taken from the ecoinvent 2.2 database (molasses from sugar beets) and includes consumption of water. For this reason the water footprint of the scenarios was investigated using a more reliable method, AWaRe (Boulay et al. 2011, 2015). The water footprints of the BIORARE, BAU and water-BES scenarios are shown in Figure 11. Overall, the BAU scenario, in this case Reverdia, is the least advantageous regarding water scarcity. Cultivating the biomass used to produce biosuccinic acid in industrial microbial fermentation requires a large amount of water. The two-step AD makes no significant contribution. Indeed, the main contribution to the water footprint is caused by the production of biosuccinic acid. In the BIORARE and the 
water-BES scenarios, the purification step represents the major contribution due to background processes involving hydrochloric acid.

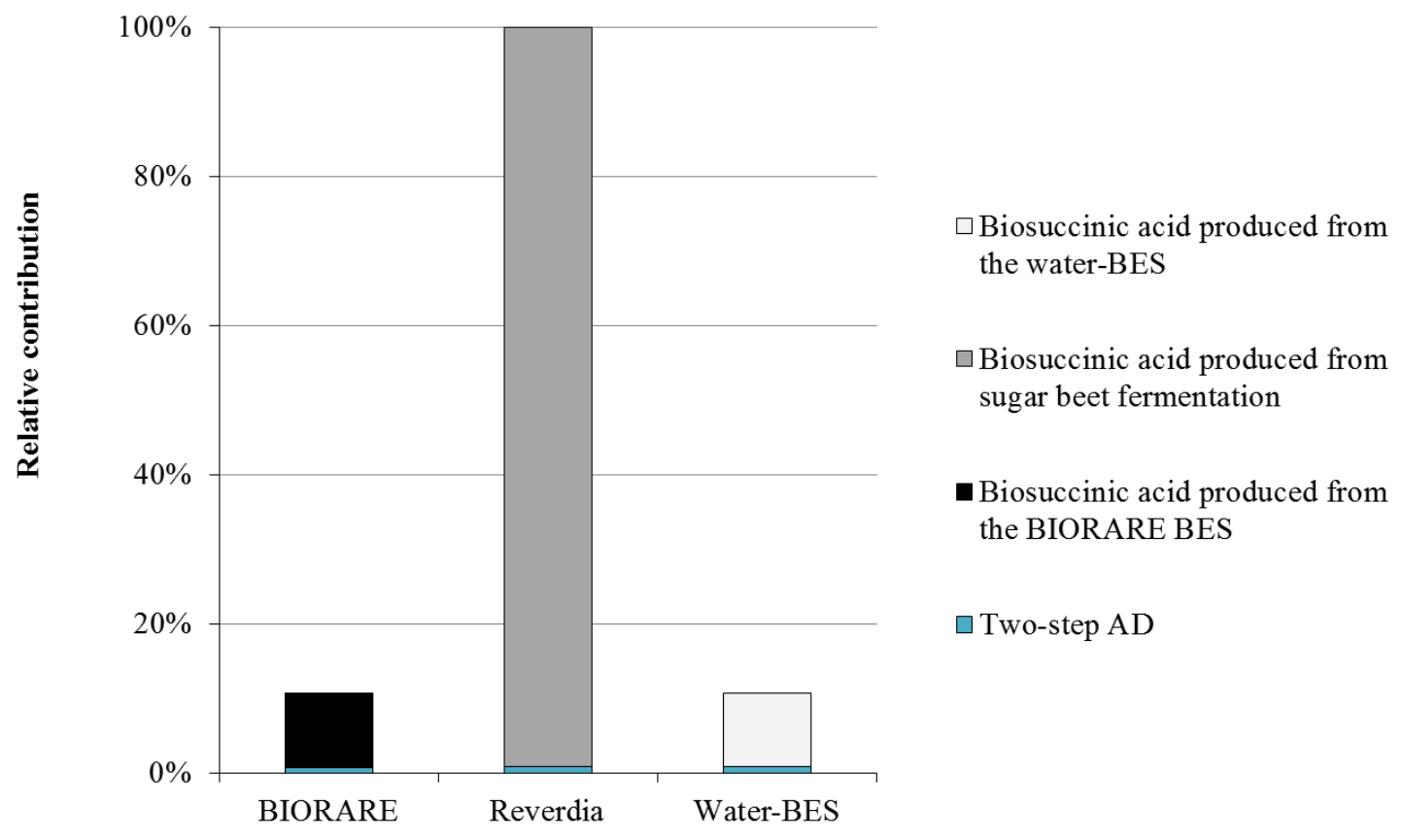

Fig. 11 Comparison of the water footprint of the scenarios BIORARE, BAU and water-BES when producing one kiloton of biosuccinic (AWaRe method)

\section{Discussion}

The comparative LCAs of this study showed that the biosuccinic acid production part has significant influence on the environmental performances of the BIORARE scenario, discounting the contribution of the two-step AD. However, trade-offs were identified between impact categories. These results are vulnerable to modelling limitations and thus data quality. When comparing a mature system with a non-mature one, an imbalance in the representativeness of data is inevitable. Indeed, a mature system implies a relative representativeness of technological data and temporal scale, whereas a non-mature system is by nature defined with low reliable and unrepresentative data. For this reason, such comparisons are to be taken carefully. First, the results should always be transparent and not lead to an inflexible conclusion. Then, sensitivity assessment could be performed in order to deal with modelling limitations. In the case of the BIORARE scenario, a sensitivity assessment would require value ranges, data on industrial-scale feasibility and an analysis of flow dependency. 
The difficulty in performing such assessment is that the BIORARE technology is here a proof of concept developed incrementally through experimentations, expert calculations and literature review. As a consequence, the calculations are not stabled enough to provide value intervals, in addition to the dependency between parameters. However, it could be of interest to assess value intervals based on theoretical calculations of the parameters of the BES unit. They could have a significant influence on the environmental performances of the BIORARE scenario. For instance, if the current density of the BES unit varies, then the electricity cost, the amount of anodic input and the electrode quantity vary along.

As shown in Figures 7 and 9, the electricity input from an external source has a significant contribution to the environmental impacts and depend on the amount of electricity produced by the cogeneration unit. The latter depends on the amount of substrate treated in the digestion unit, for which the BES parameters are calibrated, thus highlighting interdependency, called synergies, between the input/output flows of the BIORARE concept. For this reason, a research agenda could be set in order to assess the consequences of the BES parameters variation on the system productivity itself and the two-step AD operation. Indeed, the latter contributes significantly to climate change because of the $\mathrm{CO}_{2}$ emissions of the fermentation, the digestion and the cogeneration steps. The first assumption was to direct the $\mathrm{CO}_{2}$ from the fermentation unit towards the BES cathodic compartment because of its purity, i.e. approximately $80 \mathrm{v} . \%$. However, the quantity of $\mathrm{CO}_{2}$ produced in the fermentation plant is not enough to meet the BES need for $\mathrm{CO}_{2}$. For this reason, the management of $\mathrm{CO}_{2}$ streams could be called into question. The biogas produced during the anaerobic digestion process is generally composed of $40 \mathrm{v} . \%$ of $\mathrm{CO}_{2}$. It would be of interest to analyse the sensitivity of the synergy involving $\mathrm{CO}_{2}$ streams between the BES unit and the anaerobic digestion unit. The synergy would be achieved by injecting the biogas directly into the bio-cathode compartment where the microbial community would use the required amount of $\mathrm{CO}_{2}$ to produce the targeted biomolecules, thus producing a "purer" biogas with a higher $\mathrm{CH}_{4}$ content, but there is no guarantee this is feasible at industrial scale. 
The lack of scaling relevance makes it difficult to draw reliable conclusions. In the present study, the data used to model the BIORARE concept and the BAU technologies were carefully chosen to be consistent with the scenarios. Despite the quest for quality data, the production scale can be identified as a weak point. Indeed, the purification step of the biosuccinic acid and the lifetime hypothesis of the BES materials could be put forward as arguments. First, the technology used for the purification of biosuccinic acid was shown to be an eco-unfriendly process. The ways of purifying biomolecules with a BES could be argued because so far no high-fidelity technology exists to recover chemicals from such systems at a large scale. A LCA agenda would be to perform a comparative LCA of all existing relevant purification technologies regardless their TRL level. The second scaling sensitive point of the BIORARE concept is the consumable materials. The contribution of the electrodes and the membrane production to potential impacts was low (see Figure 7) but could increase if the lifetime is actually shorter. What is more, the lifetime of the BES materials may be either longer or shorter depending on the biomolecule targeted but data are difficult to find because of the industrial secrecy and the lack of hindsight. It would be useful to conduct the same study using a panel of different molecules which can be produced by a BES, for example butanol, acrylic acid and 1,4-butanediol (Pandit and Mahadevan 2011; Zaybak et al. 2013; Sadhukhan et al. 2016).

To tackle the issue of market competitiveness, we searched for an existing non-mature technology that could compete with the BIORARE technology. The BES technology has been studied for years in both microbial and abiotic conditions. The water-based BES was developed in the latter. When comparing the BIORARE concept with a similar concept that needs water instead of waste-based substrate, it appears to be more advantageous to use a microbial BES rather than an abiotic BES. The outcome of this comparative LCA is promising but it is based on theoretical calculations and hypotheses. For instance, the electric potential difference of the water-based BES is an optimistic value that could be higher at larger scale, thus increasing the energy demand of the BES unit. It would then be of interest to 
study the BIORARE concept and the water-BES system at pilot scale in the field in order to adjust the electrochemical parameters.

\section{Conclusions}

Using an interdisciplinary approach to implement a bioelectrochemical system (BES) within a two-step anaerobic digestion (AD) plant would enable the production of biosuccinic acid and energy (biogas) while at the same time reducing municipal bio-waste. The advantage of such coupling is creating synergies between the two systems: the distribution of the energy resulting from biogas combustion and of the co-products of fermentation, i.e. carbon dioxide $\left(\mathrm{CO}_{2}\right)$ and a carbon-rich substrate. Conceiving a synergistic technology may reduce environmental burdens. Indeed, using $\mathrm{CO}_{2}$ from a fermentation unit located nearby in addition to using heat and electricity produced from biogas, would avoid having to purchase external supplies.

However, this does not entirely avoid environmental impacts. Throughout the present paper, the BIORARE concept has been shown to be more or less competitive than alternative ways of producing biosuccinic acid depending on the impact category considered as well as on the alternative production technology studied. Beyond the environmental impacts caused by the two-step $\mathrm{AD}$, the production of biosuccinic acid with a BES unit has potential impacts due to the background processes of electrode, membrane and purification technologies. It is possible to predict that reviewing the BES design and possible synergies between the process units would change the environmental impacts of the system under study, but not whether the change would be positive or negative way. The same applies to the quantity of materials required, because the BES performances could be enhanced by increasing the current density of the BES, thus resulting in a smaller volume of electrodes and membrane (in other words, a smaller BES). This assumption could be checked by conducting a sensitivity analysis, which will be the subject of a future prospective paper. 


\section{Acknowledgments}

The authors would like to thank the French National Research Agency for supporting the

BIORARE project (ANR-10-BTBR-02).

\section{References}

Azapagic A (1999) Life cycle assessment and its application to process selection, design and optimisation. Chem Eng J 73:1-21

Bajracharya S, Sharma M, Mohanakrishna G, Benneton XD, Strik D, Sarma PM, Pant D (2016) An overview on emerging bioelectrochemical systems (BESs): Technology for sustainable electricity, waste remediation, resource recovery, chemical production and beyond. Renew Energy 98:153-170. doi: 10.1016/j.renene.2016.03.002

Boulay A-M, Bare J, Camillis CD, et al (2015) Consensus building on the development of a stress-based indicator for LCA-based impact assessment of water consumption: outcome of the expert workshops. Int J Life Cycle Assess 20:577-583. doi: $10.1007 / \mathrm{s} 11367-015-0869-8$

Boulay A-M, Bulle C, Bayart J-B, Deschênes L, Margni M (2011) Regional Characterization of Freshwater Use in LCA: Modeling Direct Impacts on Human Health. Environ Sci Technol 45:8948-8957. doi: 10.1021/es1030883

Bretz K (2015) Succinic Acid Production in Fed-Batch Fermentation of Anaerobiospirillum succiniciproducens Using Glycerol as Carbon Source. Chem Eng Technol 38:16591664. doi: 10.1002/ceat.201500015

Cao Y, Zhang R, Sun C, Cheng T, Liu Y, Xian M (2013) Fermentative Succinate Production: An Emerging Technology to Replace the Traditional Petrochemical Processes, Fermentative Succinate Production: An Emerging Technology to Replace the Traditional Petrochemical Processes. BioMed Res Int BioMed Res Int, 2013:e723412. doi: $10.1155 / 2013 / 723412,10.1155 / 2013 / 723412$

Cherubini F, Peters GP, Berntsen T, Strømman AH, Hertwich E (2011) CO2 emissions from biomass combustion for bioenergy: atmospheric decay and contribution to global warming. GCB Bioenergy 3:413-426. doi: 10.1111/j.1757-1707.2011.01102.x

Cherubini F, Strømman AH, Hertwich E (2013) Biogenic CO2 fluxes from bioenergy and climate-A response. Ecol Model 253:79-81. doi: 10.1016/j.ecolmodel.2013.01.007

Cok B, Tsiropoulos I, Roes AL, Patel MK (2014) Succinic acid production derived from carbohydrates: An energy and greenhouse gas assessment of a platform chemical toward a bio-based economy. Biofuels Bioprod Biorefining 8:16-29. doi: $10.1002 / \mathrm{bbb} .1427$

Conrado RJ, Haynes CA, Haendler BE, Toone EJ (2013) Electrofuels: A New Paradigm for Renewable Fuels. In: Lee JW (ed) Advanced Biofuels and Bioproducts. Springer New York, New York, NY, pp 1037-1064

del Pilar Anzola Rojas M, Zaiat M, Gonzalez ER, et al (2018) Effect of the electric supply interruption on a microbial electrosynthesis system converting inorganic carbon into acetate. Bioresour Technol 266:203-210. doi: 10.1016/j.biortech.2018.06.074 
Dumas C, Basseguy R, Bergel A (2008) Microbial electrocatalysis with Geobacter sulfurreducens biofilm on stainless steel cathodes. Electrochimica Acta 53:2494-2500. doi: 10.1016/j.electacta.2007.10.018

Dunn JB, Adom F, Sather N, Han J, Snyder S (2015) Life-cycle Analysis of Bioproducts and Their Conventional Counterparts in GREET. U.S. Department of Energy, Argonne National Laboratory

Escamilla-Alvarado C, Poggi-Varaldo HM, Ponce-Noyola MT (2017) Bioenergy and bioproducts from municipal organic waste as alternative to landfilling: a comparative life cycle assessment with prospective application to Mexico. Environ Sci Pollut Res 24:25602-25617. doi: 10.1007/s11356-016-6939-z

Espinosa N, Laurent A, Krebs FC (2015) Ecodesign of organic photovoltaic modules from Danish and Chinese perspectives. Energy Environ Sci 8:2537-2550. doi: 10.1039/C5EE01763G

European Commission (2018) Municipal waste by waste operations - Eurostat. http://ec.europa.eu/eurostat/web/products-datasets/-/env_wasmun. Accessed $23 \mathrm{Mar}$ 2018

European Commission (2014) Horizon 2020, work programme 2014 - 2015

European Commission (2010a) International Reference Life Cycle Data System (ILCD) Handbook - Framework and Requirements for Life Cycle Impact Assessment Models and Indicators. First edition. Publications Office of the European Union, Luxembourg

European Commission (2010b) International Reference Life Cycle Data System (ILCD) Handbook - General guide for Life Cycle Assessment - Detailed guidance. Publications Office, Luxembourg

European Commission, Joint Research Centre, Institute for Environment and Sustainability (2010) International Reference Life Cycle Data System (ILCD) Handbook - General guide for Life Cycle Assessment - Detailed guidance. Publications Office, Luxembourg

Evans G (2001) Biowaste and Biological Waste Treatment. Earthscan

Farahani SS, Asoodar MA (2017) Life cycle environmental impacts of bioethanol production from sugarcane molasses in Iran. Environ Sci Pollut Res 24:22547-22556. doi: $10.1007 / \mathrm{s} 11356-017-9909-1$

Foley JM, Rozendal RA, Hertle CK, Lant PA, Rabaey K (2010) Life Cycle Assessment of High-Rate Anaerobic Treatment, Microbial Fuel Cells, and Microbial Electrolysis Cells. Environ Sci Technol 44:3629-3637. doi: 10.1021/es100125h

Fouilland E, Vasseur C, Leboulanger C, (2014) Coupling algal biomass production and anaerobic digestion: Production assessment of some native temperate and tropical microalgae. Biomass Bioenergy 70:564-569. doi: 10.1016/j.biombioe.2014.08.027

Foulet A, Birot M, Sonnemann G, Deleuze H (2015) Life cycle assessment of producing emulsion-templated porous materials from Kraft black liquor - comparison of a vegetable oil and a petrochemical solvent. J Clean Prod 91:180-186. doi: 10.1016/j.jclepro.2014.12.035 
Francmanis E, Khabdullin A, Khabdullin A, Khabdullina Z, Khabdullina G (2016) Comparative Environmental Analysis of Microbial Electrochemical Systems. Energy Procedia 95:564-568. doi: 10.1016/j.egypro.2016.09.086

Lam KF, Leung CCJ, Lei HM, Lin CSK (2014) Economic feasibility of a pilot-scale fermentative succinic acid production from bakery wastes. Food Bioprod Process 92:282-290. doi: 10.1016/j.fbp.2013.09.001

Glassner DA, Elankovan P, Beacom DR, Berglund KA (1995) Purification process for succinic acid produced by fermentation. Appl Biochem Biotechnol 51-52:73-82. doi: 10.1007/BF02933412

Guest G, Cherubini F, Strømman AH (2013) Global Warming Potential of Carbon Dioxide Emissions from Biomass Stored in the Anthroposphere and Used for Bioenergy at End of Life. J Ind Ecol 17:20-30. doi: 10.1111/j.1530-9290.2012.00507.x

Hansen TL, Schmidt JE, Angelidaki I, et al (2004) Method for determination of methane potentials of solid organic waste. Waste Manag 24:393-400. doi: 10.1016/j.wasman.2003.09.009

Heijungs R, Guinée JB, Huppes G, et al (1992) Environmental life cycle assessment of products: guide and backgrounds (Part 1). CML, Leiden

Heijungs, R., Guinée, J.B., Huppes, G., et al (2001) Environmental life cycle assessment of products: guide and backgrounds (Part 2). In: Environmental Management - Life Cycle Assessment - Principles and Framework

Huh YS, Jun Y-S, Hong YK, Song H, Lee SY, Hong WH (2006) Effective purification of succinic acid from fermentation broth produced by Mannheimia succiniciproducens. Process Biochem 41:1461-1465. doi: 10.1016/j.procbio.2006.01.020

ISO (2006a) ISO 14044:2006 - Environmental management - Life cycle assessment Requirements and guidelines. International Organization for Standardization (ISO), Geneva, Switzerland

ISO (2006b) ISO 14040:2006 - Environmental management - Life cycle assessment Principles and framework. International Organization for Standardization (ISO), Geneva, Switzerland

Jourdin L (2015) Microbial electrosynthesis from carbon dioxide: performance enhancement and elucidation of mechanisms. The University of Queensland

Kootstra (2017) Direct processing of sugar beet using Betaprocess : Chembeet WP1 and WP2. ACRRES, Wageningen University \& Research, Wageningen

LeRoy RL (1983) Industrial water electrolysis: Present and future. Int J Hydrog Energy 8:401-417. doi: 10.1016/0360-3199(83)90162-3

Li W-W, Yu H-Q, He Z (2014) Towards sustainable wastewater treatment by using microbial fuel cells-centered technologies. Energy Environ Sci 7:911-924. doi: 10.1039/C3EE43106A

Logan BE, Rabaey K (2012) Conversion of Wastes into Bioelectricity and Chemicals by Using Microbial Electrochemical Technologies. Science 337:686-690. doi: 10.1126/science. 1217412 
Lovley DR (2006) Microbial fuel cells: novel microbial physiologies and engineering approaches. Curr Opin Biotechnol 17:327-332. doi: 10.1016/j.copbio.2006.04.006

Luque R, Lin CSK, Du C, et al (2009) Chemical transformations of succinic acid recovered from fermentation broths by a novel direct vacuum distillation-crystallisation method. Green Chem 11:193-200. doi: 10.1039/B813409J

Manfredi S, Pant R (2011) Supporting environmentally sound decisions for bio-waste management: a practical guide to Life Cycle Thinking (LCT) and Life Cycle Assessment (LCA). Joint Research Centre - Institute for Environment and Sustainability, Luxembourg

Mankins JC (1995) Technology readiness levels: a white paper. Off Space Access Technol Adv Concepts Off

McCreery RL (2008) Advanced Carbon Electrode Materials for Molecular Electrochemistry. Chem Rev 108:2646-2687. doi: 10.1021/cr068076m

Mitterpach J, Hroncová E, Ladomerský J, Balco K (2017) Environmental analysis of waste foundry sand via life cycle assessment. Environ Sci Pollut Res 24:3153-3162. doi: $10.1007 / \mathrm{s} 11356-016-8085-\mathrm{z}$

Morales M, Ataman M, Badr S, et al (2016) Sustainability assessment of succinic acid production technologies from biomass using metabolic engineering. Energy Environ Sci 9:2794-2805. doi: 10.1039/C6EE00634E

Moscoviz R, de Fouchécour F, Santa-Catalina G, Bernet N, Trably E (2017) Cooperative growth of Geobacter sulfurreducens and Clostridium pasteurianum with subsequent metabolic shift in glycerol fermentation. Sci Rep 7:44334. doi: 10.1038/srep44334

Pandit AV, Mahadevan R (2011) In silico characterization of microbial electrosynthesis for metabolic engineering of biochemicals. Microb Cell Factories 10:76. doi: $10.1186 / 1475-2859-10-76$

Pant D, Singh A, Van Bogaert G, Alvarez-Gallego Y, Diels L, Vanbroekhoven K (2011) An introduction to the life cycle assessment (LCA) of bioelectrochemical systems (BES) for sustainable energy and product generation: Relevance and key aspects. Renew Sustain Energy Rev 15:1305-1313. doi: 10.1016/j.rser.2010.10.005

Patel DA, Meesters K, den Uil H, de Jong E, Blok K (2012) Sustainability assessment of novel chemical processes at early stage: application to biobased processes. Energy Environ Sci 5:8430-8444. doi: 10.1039/C2EE21581K

Pinazo JM, Domine ME, Parvulescu V, Petru F (2015) Sustainability metrics for succinic acid production: A comparison between biomass-based and petrochemical routes. Catal Today 239:17-24. doi: 10.1016/j.cattod.2014.05.035

Pocaznoi D, Calmet A, Etcheverry L, Erable B, Bergel A (2012) Stainless steel is a promising electrode material for anodes of microbial fuel cells. Energy Environ Sci 5:96459652. doi: 10.1039/C2EE22429A

Pradel M, Aissani L, Villot J, Baudez J-C, Laforest V (2016) From waste to added value product: towards a paradigm shift in life cycle assessment applied to wastewater sludge - a review. J Clean Prod 131:60-75. doi: 10.1016/j.jclepro.2016.05.076 
Quéméner ED-L, Bridier A, Tian J-H, Madigou C, Qi Y, Bouchez Tl (2018) Biorefinery for heterogeneous organic waste using microbial electrochemical technology. Green Chem Spec Issue Submitted

Rabaey K, Rozendal RA (2010a) Microbial electrosynthesis - revisiting the electrical route for microbial production. Nat Rev Microbiol 8:706-716. doi: 10.1038/nrmicro2422

Ras M, Lardon L, Bruno S, Bernet N, Steyer J-P (2011) Experimental study on a coupled process of production and anaerobic digestion of Chlorella vulgaris. Bioresour Technol 102:200-206. doi: 10.1016/j.biortech.2010.06.146

Reddy MV, ElMekawy A, Pant D (2018) Bioelectrochemical synthesis of caproate through chain elongation as a complementary technology to anaerobic digestion. Biofuels Bioprod Biorefining. doi: 10.1002/bbb.1924

Richard C (2013) Intégration d'une étape de production de bioéthanol en culture mixte au sein d'une filière de traitement de déchets solides par méthanisation. AgroParisTech

Rozendal RA, Hamelers HVM, Rabaey K, Keller J, Buisman CJN (2008a) Towards practical implementation of bioelectrochemical wastewater treatment. Trends Biotechnol 26:450-459. doi: 10.1016/j.tibtech.2008.04.008

Rozendal RA, Jeremiasse AW, Hamelers HVM, Buisman CJN (2008b) Hydrogen Production with a Microbial Biocathode. Environ Sci Technol 42:629-634. doi: 10.1021/es071720+

Sadhukhan J, Lloyd JR, Scott K, et al (2016) A critical review of integration analysis of microbial electrosynthesis (MES) systems with waste biorefineries for the production of biofuel and chemical from reuse of CO2. Renew Sustain Energy Rev 56:116-132. doi: 10.1016/j.rser.2015.11.015

Schäfer H, Beladi-Mousavi SM, Walder L, et al (2015a) Surface Oxidation of Stainless Steel: Oxygen Evolution Electrocatalysts with High Catalytic Activity. ACS Catal 5:26712680. doi: 10.1021/acscatal.5b00221

Schäfer H, Sadaf S, Walder L, et al (2015b) Stainless steel made to rust: a robust watersplitting catalyst with benchmark characteristics. Energy Environ Sci 8:2685-2697. doi: 10.1039/C5EE01601K

Srikanth S, Kumar M, Singh MP, Das BP (2016) Bioelectro Chemical Systems: A Sustainable and Potential Platform for Treating Waste. Procedia Environ Sci 35:853-859. doi: 10.1016/j.proenv.2016.07.102

Sun M, Zhai L-F, Li W-W, Yu H-Q (2016) Harvest and utilization of chemical energy in wastes by microbial fuel cells. Chem Soc Rev 45:2847-2870. doi: 10.1039/C5CS00903K

Sutton MD, Doran-Peterson JB (2001) Fermentation of Sugarbeet Pulp for Ethanol Production Using Bioengineered Klebsiella oxytoca Strain P2. J Sugarbeet Res 38:1934. doi: $10.5274 /$ jsbr.38.1.19

Tang X, Madronich S, Wallington T, Calamari D (1998) Changes in tropospheric composition and air quality. J Photochem Photobiol B 46:83-95. doi: 10.1016/S10111344(98)00187-0 
Thinkstep (2016) GaBi Software-System and Database for the Life Cycle Engineering. Leinfelden-Echterdingen, Germany

U.S. Department of Energy (2010) Environmental Assessment for the Myriant Succinic Acid Biorefinery (MYSAB), Lake Providence, Louisiana. Office of Energy Efficiency and Renewable Energy, Golden, Colorado

Wang X, Cheng S, Feng Y, Merrill MD, Saito T, Logan EL (2009) Use of Carbon Mesh Anodes and the Effect of Different Pretreatment Methods on Power Production in Microbial Fuel Cells. Environ Sci Technol 43:6870-6874. doi: 10.1021/es900997w

Weastra (2012) Determination of market potential for selected platform chemicals - EU project BioConSept. weastra, s.r.o.

Wrana N, Sparling R, Cicek N, Levin DB (2010) Hydrogen gas production in a microbial electrolysis cell by electrohydrogenesis. J Clean Prod 18, Supplement 1:S105-S111. doi: 10.1016/j.jclepro.2010.06.018

Yadav P, Samadder SR (2018) Environmental impact assessment of municipal solid waste management options using life cycle assessment: a case study. Environ Sci Pollut Res 25:838-854. doi: 10.1007/s11356-017-0439-7

Yan Q, Zhao M, Miao H, et al (2010) Coupling of the hydrogen and polyhydroxyalkanoates (PHA) production through anaerobic digestion from Taihu blue algae. Bioresour Technol 101:4508-4512. doi: 10.1016/j.biortech.2010.01.073

Yang N, Waldvogel SR, Jiang X (2016) Electrochemistry of Carbon Dioxide on Carbon Electrodes. ACS Appl Mater Interfaces 8:28357-28371. doi: 10.1021/acsami.5b09825

Yu F, Li F, Sun L (2016) Stainless steel as an efficient electrocatalyst for water oxidation in alkaline solution. Int $\mathrm{J}$ Hydrog Energy 41:5230-5233. doi: 10.1016/j.ijhydene.2016.01.108

Zabed H, Faruq G, Sahu JN, Airun MS, Hashim R, Boyce AN (2014) Bioethanol Production from Fermentable Sugar Juice, Bioethanol Production from Fermentable Sugar Juice. Sci World J Sci World J 2014:e957102. doi: 10.1155/2014/957102

Zaybak Z, Pisciotta JM, Tokash JC, Logan BE (2013) Enhanced start-up of anaerobic facultatively autotrophic biocathodes in bioelectrochemical systems. J Biotechnol 168:478-485. doi: 10.1016/j.jbiotec.2013.10.001

Zhang Q, Hu J, Lee D-J (2016) Biogas from anaerobic digestion processes: Research updates. Renew Energy 98:108-119. doi: 10.1016/j.renene.2016.02.029

Zhang T, Nie H, Bain TS, et al (2013) Improved cathode materials for microbial electrosynthesis. Energy Env Sci 6:217-224. doi: 10.1039/C2EE23350A 